\title{
17 $\beta$-estradiol ameliorates oxidative stress and blue light-emitting diode-induced retinal degeneration by decreasing apoptosis and enhancing autophagy
}

This article was published in the following Dove Press journal:

Drug Design, Development and Therapy

\section{Qingquan Weil,* \\ Xiuwei Liang ${ }^{2, *}$ \\ Ye Peng ${ }^{3, *}$ \\ Donghui $\mathrm{Yu}^{\prime}$ \\ Ruiling Zhang' \\ Huizi Jin' \\ Jiaqi Fan' \\ Wenting Cai' \\ Chengda Ren' \\ Jing $Y^{1,4}$}

'Department of Ophthalmology, Shanghai Tenth People's Hospital Affiliated with Tongji University, Shanghai, People's Republic of China;

${ }^{2}$ Department of Ophthalmology, Nanchang University, Nanchang, People's Republic of China;

${ }^{3}$ Department of Clinical Laboratory, Shanghai Tenth People's Hospital Affiliated with Tongji University, Shanghai, People's Republic of China; ${ }^{4}$ Department of Ophthalmology, Ninghai First Hospital, Zhejiang,

People's Republic of China

*These authors contributed equally to this work

\footnotetext{
Correspondence: Jing Yu; Chengda Ren Department of Ophthalmology, Shanghai Tenth People's Hospital Affiliated with Tongji University, 30 I Middle Yanchang Road, Shanghai 200072, People's Republic of China Tel +86 2l 6630 I362 Email dryujing@aliyun.com; curiec@sina.cn
}

\begin{abstract}
Purpose: This study aimed to assess the effects of $17 \beta$-estradiol $\left(\beta \mathrm{E}_{2}\right)$ on blue light-emitting diode (LED)-induced retinal degeneration (RD) in rats and hydrogen peroxide $\left(\mathrm{H}_{2} \mathrm{O}_{2}\right)$-induced retinal pigment epithelium cell injury in humans and elucidate the protective mechanism of $\beta \mathrm{E}_{2}$ underlying these processes.

Methods: Female ovariectomized (OVX) rats were intravitreally injected with $\beta \mathrm{E} 2$ before blue LED exposure (3,000 lux, 2 hours). Retinal function and morphology were assayed via electroretinogram (ERG) and H\&E, respectively. Cell viability was assayed using the Cell Counting Kit-8. Cell ROS were measured using dichlorofluorescein fluorescence. Apoptosis was evaluated by TUNEL and Annexin V/propidium iodide staining. Gene expression and protein expression were quantified using quantitative real-time RT-PCR, Western blotting, and immunohistochemistry. Autophagosomes were examined by electron microscopy.

Results: Female OVX rats were exposed to blue LED, inducing RD. $\beta \mathrm{E}_{2}$ significantly prevented the reduction in the a- and b-wave ERG amplitudes and the disruption of retinal structure, the loss of photoreceptor cells, and the decrease in the thickness of the outer nuclear layer caused by blue LED exposure. $\beta \mathrm{E}_{2}$ also decreased cell apoptosis in the retina in blue LED-induced RD. Additionally, $\beta \mathrm{E}_{2}$ reduced ROS levels and apoptosis in $\mathrm{H}_{2} \mathrm{O}_{2}$-treated human retinal pigment epithelial (ARPE-19) cells. Furthermore, $\beta \mathrm{E}_{2}$ increased the protein expression of $\mathrm{p}-\mathrm{Akt}$ and $\mathrm{Bcl}-2$ and decreased the protein expression of cleaved caspase- 3 and Bax during blue LED-induced retinal damage and in $\mathrm{H}_{2} \mathrm{O}_{2}$-treated ARPE- 19 cells. $\beta \mathrm{E}_{2}$ also increased the number of autophagosomes and upregulated the expression of LC3-II/LC3-I and Beclin 1 in these processes.

Conclusion: $\beta \mathrm{E}_{2}$ protects against blue LED-induced $\mathrm{RD}$ and $\mathrm{H}_{2} \mathrm{O}_{2}$-induced oxidative stress by acting as an antioxidant, and its protective mechanism might occur by reducing apoptosis and enhancing autophagy; $\beta \mathrm{E}_{2}$ may be a novel and effective therapy for age-related macular degeneration.
\end{abstract}

Keywords: $17 \beta$-estradiol, hydrogen peroxide, retinal blue light-emitting diode degeneration, oxidative stress, apoptosis, autophagy

\section{Introduction}

Age-related macular degeneration (AMD) is the most common cause of permanent vision impairment and loss in older adults, especially postmenopausal women. ${ }^{1,2}$ The severity and progression of AMD are exacerbated following excessive exposure to environmental light, ${ }^{3}$ as photoreceptors are sensitive to a wide range of visible light conditions and intensities, leading to photoreceptor degeneration and cell death. ${ }^{4}$ 
Blue (and blue-rich white) light-emitting diodes (LEDs) cause more severe retinal degeneration (RD) than other types of LEDs. ${ }^{5}$ Previous studies have shown that the pathogenesis of retinal blue light damage involves the generation of ROS and the accumulation of oxidatively modified lipids, nucleic acids, and proteins. ${ }^{6,7}$ Thus far, various types of antioxidants, such as lutein, curcumin, and vitamins $\mathrm{A}, \mathrm{C}$, and $\mathrm{E}$, have been used to reduce RD. ${ }^{8}$ The antioxidative effects of these compounds, however, are limited. It is therefore necessary to investigate other retinal protective agents.

$17 \beta$-estradiol $\left(\beta_{2}\right)$ is a strong antioxidant in the central nervous system and has a protective effect in neurodegenerative diseases, such as Alzheimer's disease and Parkinson's disease. ${ }^{9-11} \beta \mathrm{E}_{2}$ exerts its therapeutic effect on these diseases by increasing neuronal survival, inhibiting neuronal apoptosis, and promoting axonal regeneration and synaptic sprouting. ${ }^{10,12}$ In addition, it has been demonstrated that $\beta \mathrm{E}_{2}$ has neuroprotective effects and that these effects result from its antioxidant activity. ${ }^{13} \beta \mathrm{E}_{2}$ exerts antioxidative effects in the retina of male and female adult Sprague Dawley (SD) rats and in hydrogen peroxide $\left(\mathrm{H}_{2} \mathrm{O}_{2}\right)$-treated human retinal pigment epithelial (ARPE-19) cells. ${ }^{14,15}$ However, the precise molecular mechanisms underlying this process remain unclear.

The apoptosis of retinal pigment epithelium (RPE) and photoreceptors are involved in geographic atrophy AMD. ${ }^{16}$ Previous studies have shown that acute exposure to excessive light can induce retinal pigment epithelial cell and photoreceptor apoptosis. ${ }^{17}$ The intrinsic apoptotic pathway can be activated by growth factor deprivation, DNA damage, gamma radiation, UV radiation, excessive ROS levels, virus infection, or oncogene activation. ${ }^{18}$ Several in vitro studies have shown that $\beta \mathrm{E}_{2}$ prevents the oxidative stress-induced apoptosis of retinal neurons, RPE cells, and human lens epithelial cells. ${ }^{15,19,20}$ It also has been demonstrated that $\beta \mathrm{E}_{2}$ has a protective effect against light-induced apoptosis. ${ }^{21}$

Accumulating evidence links autophagic impairment with a range of age-related neurodegenerative diseases, including $\mathrm{AMD} .^{22}$ In response to oxidative stress, autophagy is significantly increased in an attempt to remove oxidatively damaged organelles, and since RPE cells are exposed to sustained oxidative stress, autophagy is especially crucial for the maintenance of homeostasis of the RPE. ${ }^{23}$ Several studies have reported that autophagy occurs in the RPE and that acute exposure to excessive light can induce autophagy. ${ }^{24-27}$ Estrogen $\left(\mathrm{E}_{2}\right)$ has a myocardial protective role against injury induced by LPS by regulating autophagy, and $\mathrm{E}_{2}$ promotes the survival of human secretory phase endometrial stromal cells via the inhibition of CXCL12/CXCR4 upregulationmediated autophagy. ${ }^{28,29}$ Moreover, the estrogen receptor is associated with autophagy in breast cancer and papillary thyroid cancer. ${ }^{30,31}$

To investigate the underlying protective mechanism of $\beta \mathrm{E}_{2}$ for $\mathrm{RD}$ disorders such as $\mathrm{AMD}$, we used blue LEDinduced RD in rats, which is a model of RD including AMD. Furthermore, we examined the antioxidant mechanism in relation to $\mathrm{H}_{2} \mathrm{O}_{2}$-induced oxidative stress in ARPE-19 cells.

\section{Materials and methods Experimental animals}

All animals were cared for in strict accordance with the Association for Research in Vision and Ophthalmology Statement for the use of animals in vision and ophthalmic research as well as Shanghai Tenth People's Hospital guidelines for Animals in Research. Female SD rats (6-7 weeks old; $180-230 \mathrm{~g}$ ) were used in this study. All rats were housed in a specific pathogen-free facility maintained at $23^{\circ} \mathrm{C} \pm 3^{\circ} \mathrm{C}$ on a 12-hour light/dark cycle with free access to food and water. Rats were ovariectomized (OVX) 2 weeks before use. All animal studies were approved by the institutional review board of Shanghai Tenth People's Hospital (ID Number: SHDSYY 2016-1984).

\section{Intravitreal administration in rat}

The OVX female rats were anesthetized via the intraperitoneal injection of ketamine $(120 \mathrm{mg} / \mathrm{kg}$ body weight) and xylazine ( $6 \mathrm{mg} / \mathrm{kg}$ body weight) after 18 -hour dark adaptation. One drop of lidocaine hydrochloride was applied to each eye as a topical anesthetic prior to intravitreal injection (IVI). IVI was performed under red light illumination in a darkened room to preserve dark adaptation. The rats

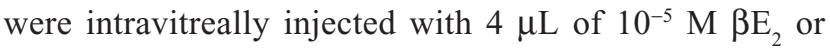
$4 \mu \mathrm{L}$ of saline as a control. ${ }^{21,32}$ After administration of the treatments, the rats were allowed 4 hours to recover before light damage. ${ }^{14}$

\section{Blue LED exposure}

Ovariectomy, as described previously, ${ }^{33}$ was performed on female rats 14 days before blue LED exposure. The OVX female rats were kept in total darkness for 24 hours. One drop of $0.5 \%$ tropicamide and $0.5 \%$ phenylephrine hydrochloride (Santen, Osaka, Japan) were applied to the cornea for papillary dilation under dim red light 30 minutes before exposure to a blue LED. The rats were exposed to 3,000

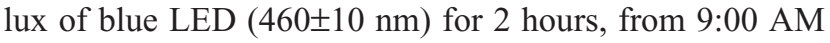


to 11:00 AM, in a light exposure box with laterally placed mirrors. After exposure to the blue LED, the rats were maintained in total darkness for 24 hours, after which a 12-hour light/dark cycle was resumed.

\section{Electroretinogram (ERG)}

ERGs were recorded at 5 days after the light exposure. All animals were kept in a completely dark room for 16 hours before the ERG recording session. Prior to examination, the rats were dark-adapted for 16 hours and were deeply anesthetized via an intramuscular injection of sodium pentobarbital $(50 \mathrm{mg} / \mathrm{kg})$ and xylazine $(6 \mathrm{mg} / \mathrm{kg})$. All procedures were prepared for recording under dim red light $(\lambda>600 \mathrm{~nm})$, and the rats were kept warm during the process. The anesthetized rats were fixed on the top of a stage, where the animals' eyes faced a flashing light at a distance of $20 \mathrm{~cm}$. A corneal electrode was mounted on the center of the cornea. Reference and ground electrodes were subcutaneously placed in the nose and tail, respectively. A single light-flash stimulus $\left(3,000 \mathrm{~cd} / \mathrm{m}^{2}\right.$ for $10 \mathrm{~ms}$ ) was applied to the eye using an LED lamp through the corneal electrode. The amplitude of the a-wave was defined as the distance from the baseline to the maximum peak of the a-wave, and the amplitude of the b-wave was defined as the distance from the maximum peak of the a-wave to the maximum peak of the b-wave.

\section{H\&E staining}

The paraffin-embedded retinal tissues were sectioned into $5 \mu \mathrm{m}$ slices. The sections were deparaffinized with xylene and a graded ethanol series $(100 \%, 95 \%, 85 \%$, and $75 \%$ ethanol). The sections were stained with hematoxylin for 5 minutes and were incubated with 1\% hydrochloric acid alcohol for 3 seconds, followed by staining with eosin for 3 minutes. Subsequently, the sections were dehydrated with a graded ethanol series $(75 \%, 85 \%, 95 \%$, and $100 \%$ ethanol) and xylene. The sections were mounted with neutral gum, and images were captured using a light microscope (Leica Microsystems, Wetzlar, Germany).

\section{TUNEL assay}

The paraffin-embedded sections ( $5 \mu \mathrm{m}$ thick) of retinal tissues were deparaffinized, treated with $0.1 \%$ Triton X-100, and blocked with $3 \% \mathrm{H}_{2} \mathrm{O}_{2}$. After washing with PBS, the sections were incubated with a mixture of terminal deoxynucleotidyl transferase (TdT) and fluorescein-labeled dUTP and then treated with converter-POD according to the manufacturer's protocol (Hoffman-La Roche Ltd, Basel, Switzerland). DAB was added, and the sections were counterstained with hematoxylin. Finally, the sections were dehydrated and photographed under a microscope.

\section{Electron microscopy}

The ARPE-19 cells and eyes without lens and cornea were fixed in $2.5 \%$ glutaraldehyde, post-fixed in $1 \%$ osmium tetroxide, dehydrated in an ascending alcohol series, and embedded in epoxy resin. Ultrathin sections were cut, stained with uranyl acetate and lead citrate, and examined under a Philips CM120 transmission electron microscope.

\section{Western blotting}

Protein extracts from the retinal tissues and cells were prepared using RIPA lysis buffer (Beyotime Biotechnology, Nanjing, Jiangsu, China) with a protease inhibitor cocktail (EMD Millipore, Billerica, MA, USA) on ice for 15 minutes. The protein concentration was determined using a BCA protein assay kit (Beyotime). The proteins were subjected to SDS-PAGE (10\%-12\%) and transferred to polyvinylidene difluoride or nitrocellulose membranes. Then, membranes were blocked with nonfat milk dissolved in Tween-20/ triethanolamine-buffered saline buffer. Subsequently, the membranes were incubated with primary antibodies against Akt (1:1,000, \#4691; Cell Signaling Technology, Danvers, MA, USA), phospho-Akt (1:2,000, \#4060; Cell Signaling Technology), Bcl-2 (1:1,000, \#3498; Cell Signaling Technology), Bax (1:1,000,\#5023; Cell Signaling Technology), Caspase-3 (1:2,000, ab184787 in rats, ab13585 in cells; Abcam, Cambridge, UK), LC3B (1:1,000, \#3868; Cell Signaling Technology), Beclin 1 (1:1,000,\#3495; Cell Signaling Technology), and $\beta$-actin (1:1,000, \#4970; Cell Signaling Technology) at $4^{\circ} \mathrm{C}$ overnight and then with secondary antibody (1:1,000, \#4412; Cell Signaling Technology) for 45 minutes at $37^{\circ} \mathrm{C}$. The protein bands were visualized using enhanced chemiluminescence reagent and were analyzed using Gel-Pro Analyzer (Media Cybernetics, Rockville, MD, USA). The results were quantified using Quantity One software (Bio-Rad, Hercules, CA, USA).

\section{Immunohistochemistry}

Retinal tissue sections ( $5 \mu \mathrm{m}$ thick) were deparaffinized with xylene and an ethanol gradient (100\%, 95\%, 85\%, and 75\% ethanol). After antigen retrieval, the sections were treated with $\mathrm{H}_{2} \mathrm{O}_{2}$ and blocked with goat serum. Then, the respective primary antibodies were added to the sections in a volume of $100 \mu \mathrm{L}$ and incubated overnight at $4^{\circ} \mathrm{C}$. After primary incubation, biotin-labeled secondary antibody (1:200, A0277; Beyotime Biotechnology) was added and incubated at $37^{\circ} \mathrm{C}$ 
for 30 minutes, followed by incubation with horseradish peroxidase-labeled avidin (A0303; Beyotime) at $37^{\circ} \mathrm{C}$ for 30 minutes. The sections were visualized with $\mathrm{DAB}$ for color development and were counterstained with hematoxylin. Section images were captured using a microscope.

\section{Cell culture}

ARPE-19 cells were obtained from Cell Bioscience Pty, Ltd. (Heidelberg, Australia). The cells were cultured in DMEM/F-12 (Thermo Fisher Scientific, Waltham, MA, USA) containing $10 \%$ fetal bovine serum and $100 \mathrm{U} / \mathrm{mL}$ penicillin. The cells were incubated at $37^{\circ} \mathrm{C}$ in a humidified incubator containing $5 \% \mathrm{CO}_{2}$. The cell culture medium was changed every 3-4 days. At $80 \%$ confluence, the cells were washed and treated with either vehicle or $\beta \mathrm{E}_{2}$ for 2 hours in phenol red-free DMEM/F12 before exposure to the appropriate concentration of $\mathrm{H}_{2} \mathrm{O}_{2}$.

\section{Cell viability assay}

ARPE-19 cells were grown to $80 \%$ confluency and then treated with $0,20,30,40,50,60,70$, and $80 \mu \mathrm{mol} / \mathrm{L}$ of $\mathrm{H}_{2} \mathrm{O}_{2}$ (Shanghai Chemical Tech, Shanghai, China) for 24 hours. Prior to measurement, $10 \mu \mathrm{L}$ of Cell Counting Kit (CCK)-8 solution (Yeasen, Shanghai, China) was added to each well and incubated at $37^{\circ} \mathrm{C}$ for 2 hours. The cells were then measured using a microplate reader (Synergy H4; BioTek, Winooski, VT, USA) at $450 \mathrm{~nm}$ to assess proliferation. Furthermore, to evaluate the effect of $\beta \mathrm{E}_{2}$ on cell proliferation, the cells were treated with $0,1,10,40,60$, and $80 \mu \mathrm{mol} / \mathrm{L}$ of $\beta \mathrm{E}_{2}$ for 2 hours before exposure to $40 \mu \mathrm{mol} / \mathrm{L}$ of $\mathrm{H}_{2} \mathrm{O}_{2}$ for 24 hours, and cell viability was then quantified. The half-maximal inhibitory concentrations $\left(\mathrm{IC}_{50}\right)$ of the ARPE-19 cells in response to treatment were calculated using CalcuSyn software (Beijing Huanzhongruichi Technology Co., Beijing, China).

\section{Measurement of ROS production}

ARPE-19 cells were grown to $80 \%$ confluency and were then incubated with either vehicle or $\beta \mathrm{E}_{2}$ before exposure to $40 \mu \mathrm{M} \mathrm{H}_{2} \mathrm{O}_{2}$. After 24 hours of incubation, cells were incubated with $10 \mu \mathrm{M}$ of $2^{\prime}, 7^{\prime}$-dichlorofluorescein diacetate
(DCFH-DA) (Sigma-Aldrich Co., St Louis, MO, USA) in serum-free medium at $37^{\circ} \mathrm{C}$ for 30 minutes. Fluorescence intensity was measured using a flow cytometer.

\section{Cell apoptosis assay}

ARPE-19 cells were treated with either vehicle or $\beta \mathrm{E}_{2}$ for 2 hours before exposure to $40 \mu \mathrm{M} \mathrm{H}_{2} \mathrm{O}_{2}$. After 24 hours of incubation, the cells were subsequently washed with PBS and stained with the Annexin V-FITC Apoptosis Detection Kit (BD BioSciences, San Jose, CA, USA) while protected from light and were analyzed using a BD FASCCanto II flow cytometer (BD BioScience). N-acetyl-1-cysteine was obtained from Beyotime. The pan-caspase inhibitor Z-VAD-FMK was obtained from Selleckchem (Houston, TX, USA).

\section{Quantitative real-time RT-PCR (qRT-PCR)}

The total RNA of cells was extracted using TRIzol reagent according to the manufacturer's instructions (Thermo Fisher Scientific). The concentration of RNA was measured using a Nanodrop 2000 spectrophotometer (Thermo Fisher Scientific), and cDNA was synthesized from $1 \mu \mathrm{g}$ of total RNA using a reverse transcription kit (Takara, Ohtsu, Shiga, Japan). Specific primers (Bioworld Technology Inc., St Louis Park, MN, USA) were used to detect EMT-related protein expression, and GAPDH was used as an internal control. miRNA quantification was performed using the 7,500 Fast Real-time PCR System (Thermo Fisher Scientific). The relative amount of each gene was measured using the $2(-\Delta \Delta \mathrm{CT})$ method. ${ }^{34}$ All qRT-PCR experiments were performed in triplicate. The primer sequences used are listed in Table 1 .

\section{Statistical analysis}

Data are expressed as the mean \pm standard deviation. The distribution of data was tested using Kolmogorov-Smirnov test. Normally distributed data were compared using oneway ANOVA followed by post hoc analysis for pair-wise comparison. When data were not normally distributed, the Kruskal-Wallis H test was used. $P$-values $<0.05$ were considered significant. The data were analyzed using SPSS 20.0 software (IBM, Armonk, NY, USA).

Table I Primers used for Q-PCR amplification

\begin{tabular}{|c|c|c|}
\hline Gene symbol & Forward 5'-3' & Reverse $5^{\prime}-3^{\prime}$ \\
\hline LC3B & CTGTTGGTGAACGGACACAG & CAATTTCATCCCGAACGTCT \\
\hline Beclin I & AGGAGAGACCCAGGAGGAAG & GGCACTTTCTGTGGACATCA \\
\hline ACTB & CCTGGCACCCAGCACAAT & GGGCCGGACTCGTCATAC \\
\hline
\end{tabular}




\section{Results}

\section{Exposure to blue LED induces RD}

To rule out an effect of endogenous $\beta \mathrm{E}_{2}$, the female rats were OVX or sham operated as described previously. ${ }^{33}$ The effect of blue LED emissions on retinal function was investigated using ERG analysis (5 days later). Based on the ERG assay (Figure 1A and B), there was no functional damage in OVX rats compared with that in the sham-operated group, although the amplitudes of the a-waves and b-waves were all decreased after blue LED emission exposure. However, the amplitudes of the a- and b-waves of the ERG were markedly reduced in the rats exposed to blue LED emission compared to those in the OVX and sham rats.

Next, the effects of blue LED emissions on retinal morphology were assayed via $\mathrm{H} \& \mathrm{E}$ staining ( 5 days later). There was no clear change in the retinal morphology of the OVX rats when compared to that in the sham-operated rats according to $\mathrm{H} \& \mathrm{E}$ staining. However, after blue LED exposure, the photoreceptors displayed destructive retinal changes, resulting in massive photoreceptor loss, pyknosis of the retinal cells, and disappearance of the outer nuclear layer (ONL). Moreover, the thickness of the ONL was significantly reduced (Figure $1 \mathrm{C}$ and D).

\section{$\beta \mathrm{E}_{2}$ administration protected the retina from blue LED}

To determine the protective effect of $\beta \mathrm{E}_{2}$ on blue LEDinduced retinal damage, we administered $\beta \mathrm{E}_{2}$ via IVI for 4 hours prior to light exposure. As shown in Figure 2A and B, blue LED exposure led to an excessive reduction in the mean amplitudes of the $\mathrm{a}$ - and $\mathrm{b}$-waves. However, $\beta \mathrm{E}_{2}$ administration protected retinal function by markedly increasing the mean amplitudes of the a- and b-waves.

Based on the H\&E assay, a severe disruption of retinal morphology was detected in blue LED-induced RD rats.
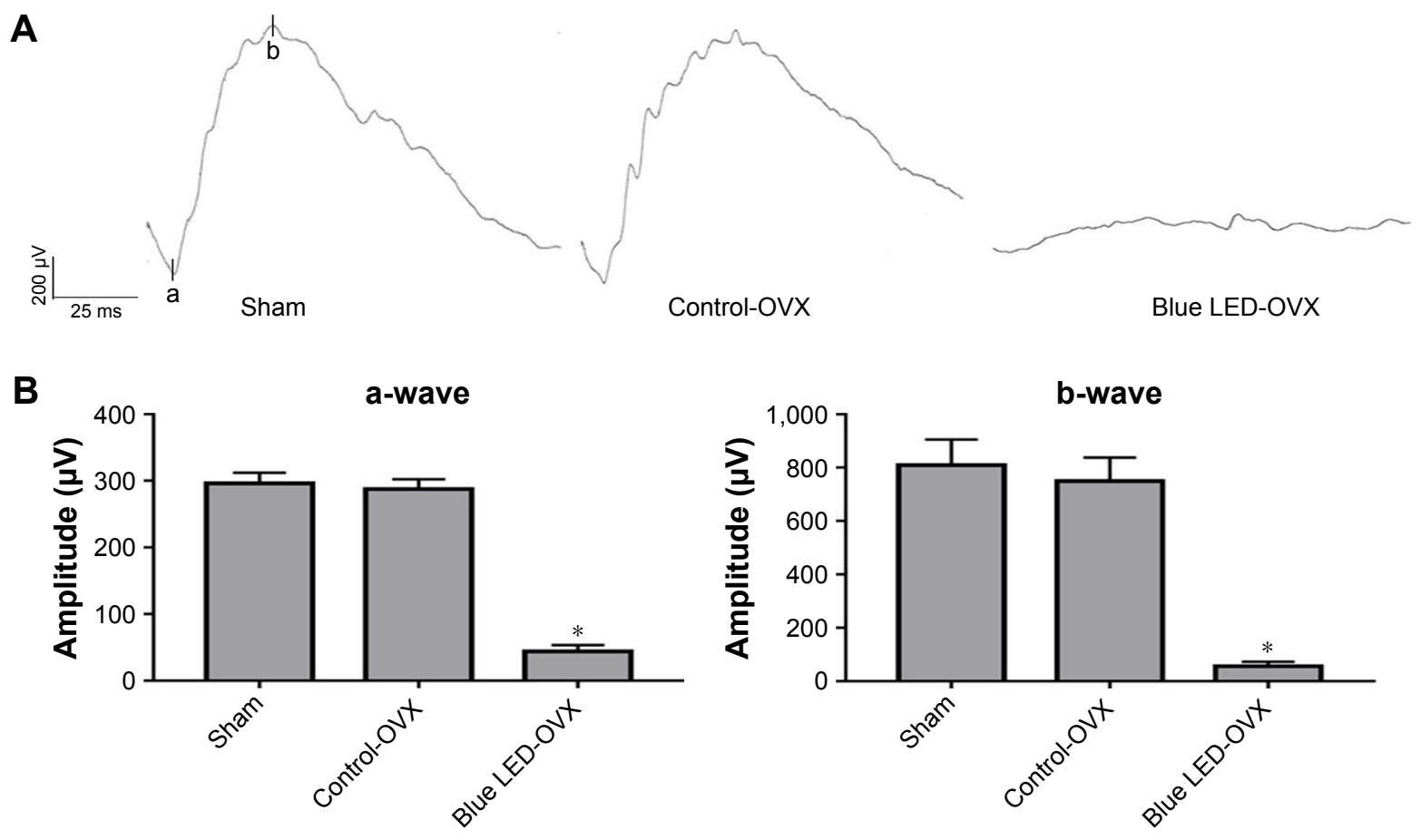

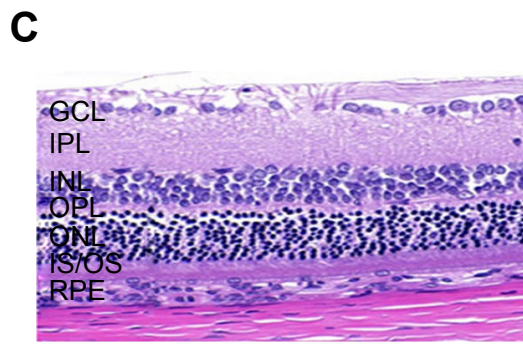

Sham

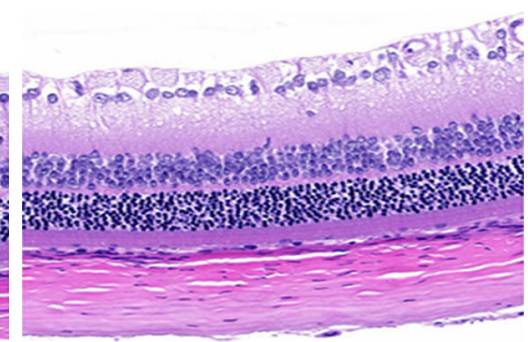

Control-OVX

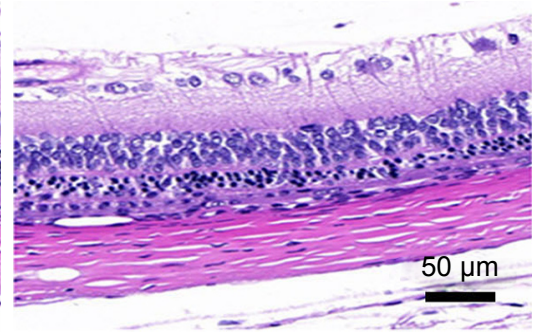

Blue LED-OVX

Figure I (Continued) 


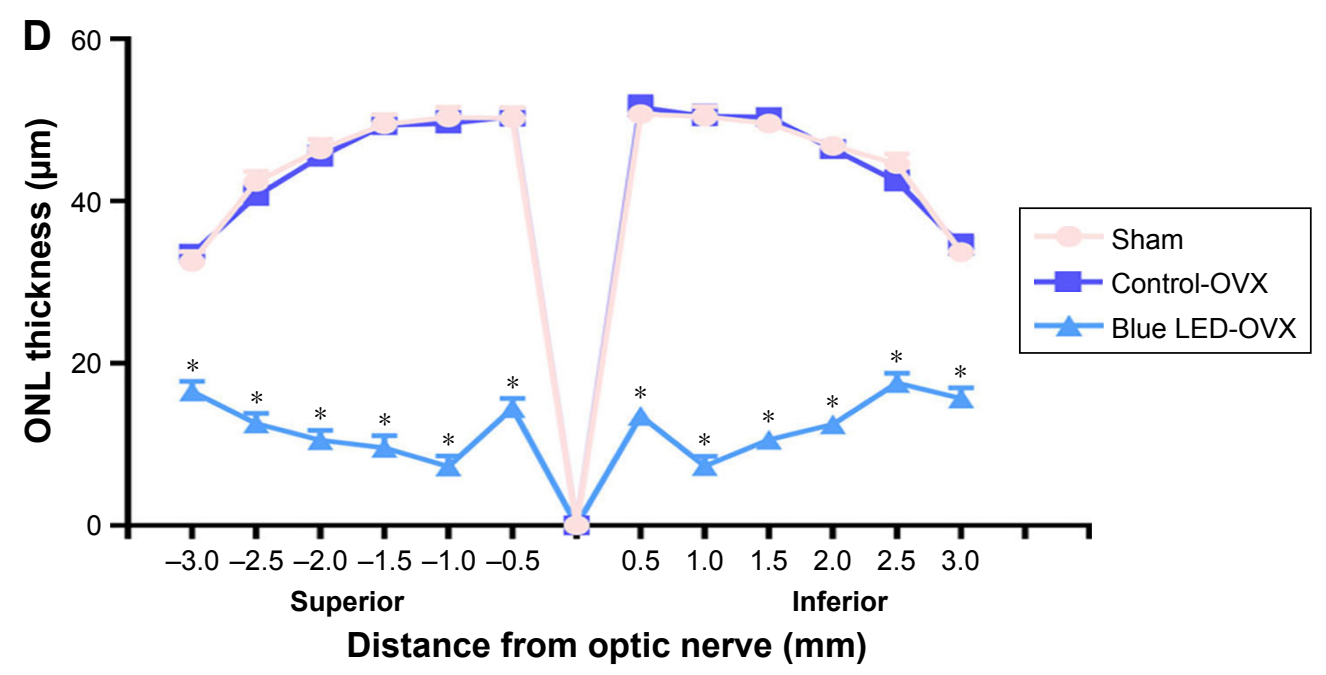

Figure I Blue LED-induced RD.

Notes: (A) The disruption of retinal function was measured via ERG following exposure to 3000 lux blue LED for $2 \mathrm{~h} 5$ days after ovariectomy. (B) Statistical analysis of the mean amplitudes of the a- and b-waves. (C) The morphological changes in the retina were measured via H\&E staining. (D) Statistical analysis of ONL thickness was measured from the optic nerve head to the superior and inferior retina in the above groups. The data represent the mean $\pm \mathrm{SEM}$. $* \mathrm{P}<0.05$, $\mathrm{n}=6$ (eye samples in each group).

Abbreviations: LED, light-emitting diode; OVX, ovariectomized; ONL, outer nuclear layer; GCL, ganglion cell layer; INL, inner nuclear layer; IPL, inner plexiform layer; IS/OS, inner segment and outer segment; OPL, outer plexiform layer; RPE, retinal pigment epithelium.

However, $\beta \mathrm{E}_{2}$ administration rescued this disruption in retinal structure by preventing the loss of photoreceptor cells and maintaining the thickness of the ONL (Figure 2C and D).

\section{$\beta \mathrm{E}_{2}$ administration protected the retina from blue LED by reducing apoptosis}

Figure $3 \mathrm{~A}$ shows representative images of the retina obtained using TUNEL staining, which revealed apoptotic cell death.
The rats exposed to blue LED emission presented a higher apoptosis rate of retinal cells than the control rats. Treatment with $\beta \mathrm{E}_{2}$ significantly decreased the apoptosis rate compared with vehicle-treated rats after blue LED exposure (Figure 3B).

Next, we measured the levels of apoptosis-related proteins (Akt, phospho-Akt, Bax, Bcl-2, and cleaved caspase-3) in the retinal tissues using Western blotting or

A
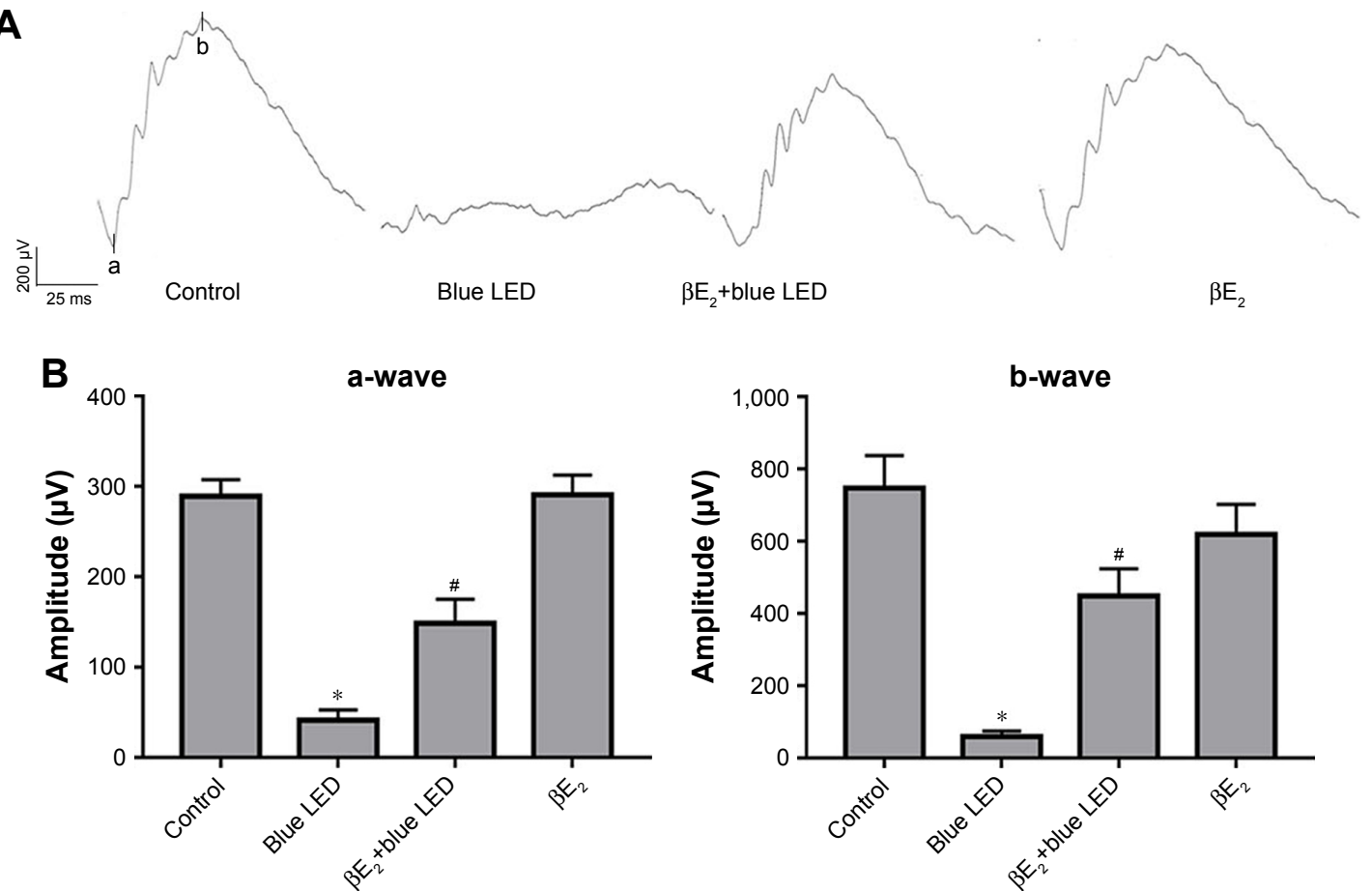

$\beta \mathrm{E}_{2}+$ blue LED

$\beta \mathrm{E}_{2}$

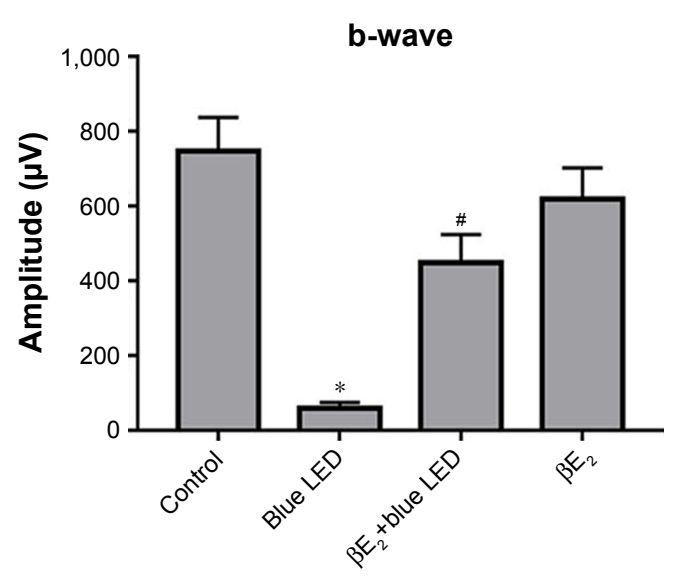




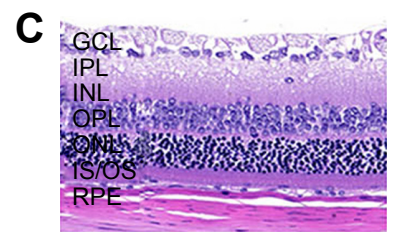

Control

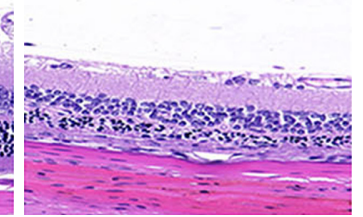

Blue LED

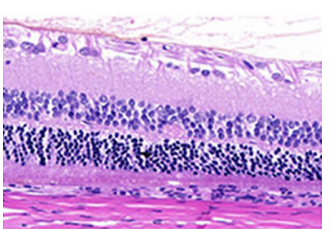

$\beta \mathrm{E}_{2}+$ blue LED

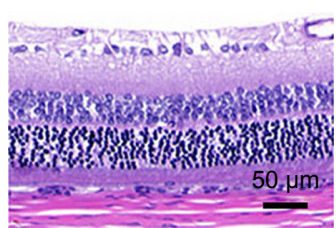

$\beta \mathrm{E}_{2}$

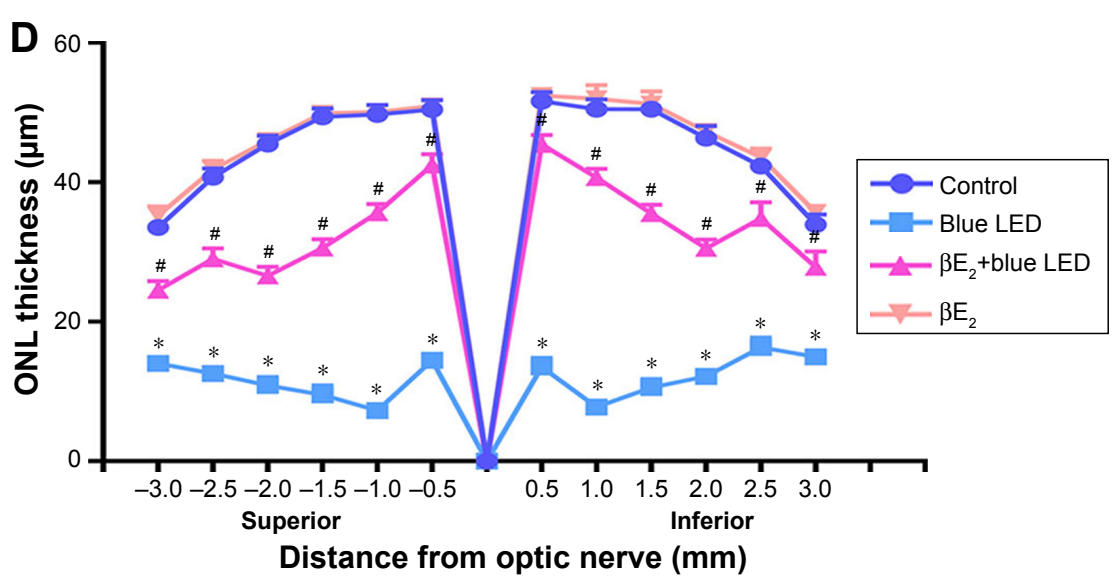

Figure $2 \beta \mathrm{E}_{2}$ administration protects against blue LED-induced RD. Female OVX rats were treated with $\beta \mathrm{E}_{2}(\mathrm{I} 0 \mu \mathrm{M})$ via IVI for $4 \mathrm{~h}$ and then exposed to 3000 lux blue LED for $2 \mathrm{~h}$. The functional and morphological changes were determined via ERG assays.

Notes: $(\mathbf{A})$ and H\&E staining $(\mathbf{C})$, respectively. The statistical analysis of the mean amplitudes of the a- and b-waves (B).ONL thickness (D) was measured from the optic nerve head to the superior and inferior retinae in the above groups. The data represent the mean $\pm S E M ; n=6$ (eye samples in each group). ${ }^{*} P<0.05$ vs. control; ${ }^{\#}<0.05$ vs. blue $L E D$. Abbreviations: $\beta \mathrm{E}_{2}$, I7 $\beta$-estradiol; LED, light-emitting diode; ONL, outer nuclear layer.

immunohistochemistry. We demonstrated that phospho-Akt, Bax, and cleaved caspase-3 levels were significantly upregulated in the retinal tissues of rats exposed to blue LED emission when compared with those in the control rats, whereas the antiapoptotic protein Bcl-2 was downregulated. $\beta \mathrm{E}_{2}$ injection reversed the blue LED-induced cell apoptosis by decreasing phospho-Akt, Bax, and caspase-3 levels and increasing Bcl-2 levels (Figure 3C-E).

\section{$\beta \mathrm{E}_{2}$ administration protected the retina from blue LED by enhancing autophagy}

As shown in Figure 4A, blue LED exposure resulted in a greater than $100 \%$ increase in the number of autopha- gosomes in vehicle-treated rats after blue LED exposure compared with those in the rats without blue LED exposure. Treatment with $\beta E_{2}$ further enhanced the events compared with vehicle-treated rats with blue LED exposure. To further investigate the molecular mechanism by which $\beta E_{2}$ exerts a protective effect on rats exposed to blue LED emission, we analyzed the potential pathways involved by Western blot and immunohistochemistry. As demonstrated in Figure 4B-D, blue LED exposure increased Beclin 1 and LC3-II/LC3-I protein levels. Intravitreal $\beta \mathrm{E}_{2}$ administration further enhanced the effect of blue LED exposure on Beclin 1 and LC3-II/LC3-I protein expression.
A

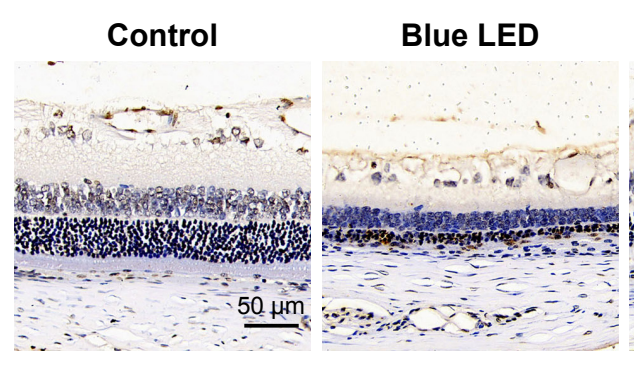

$\beta E_{2}+$ blue LED

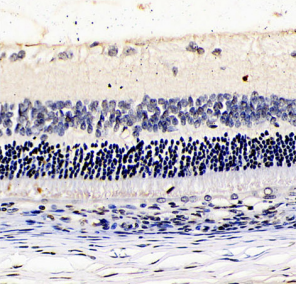

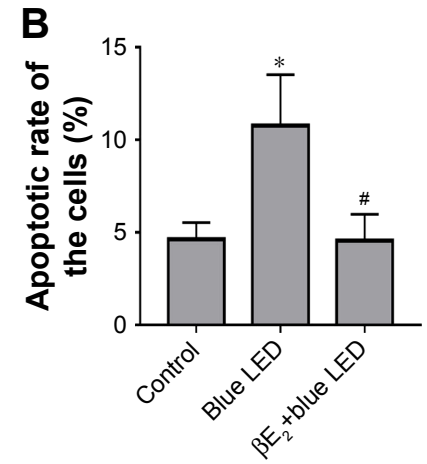

Figure 3 (Continued) 

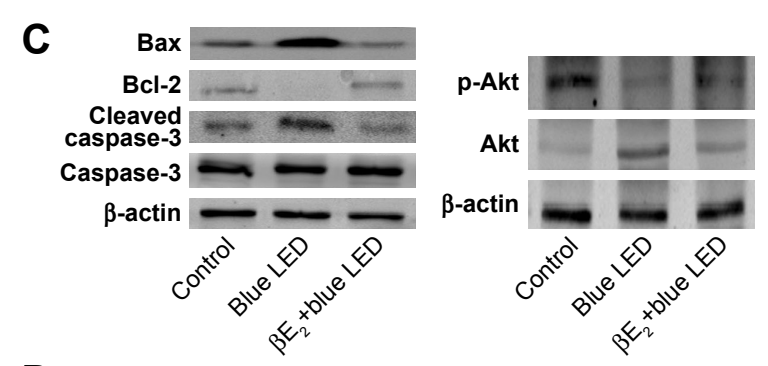

\section{E}
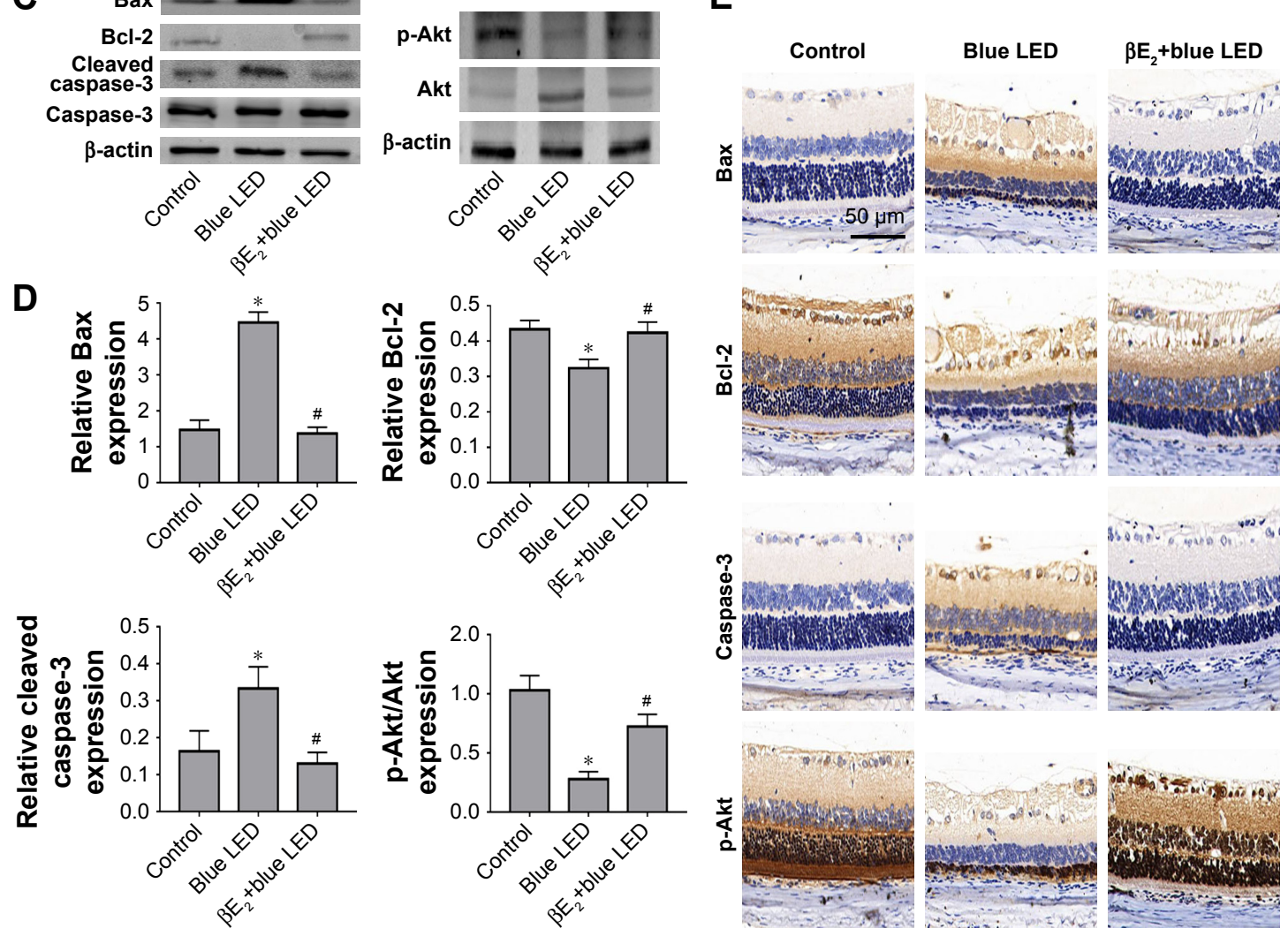

Figure $3 \beta \mathrm{E}_{2}$ administration reduces apoptosis after blue LED exposure.

Notes: (A) Apoptosis was detected using the TUNEL assay after the intravitreal administration of $\beta E_{2} 5$ days after blue LED exposure. (B) Statistical analysis of apoptotic cells on retina. (C) Bax, Bcl-2, Caspase-3, Akt and p-Akt protein levels were examined by western blotting. (D) Statistical analysis of western blot. (E) Bax, Bcl-2, Cleaved caspase- 3 , and $\mathrm{p}$-Akt expression levels were examined by immunohistochemistry. The data represent the mean $\pm S E M ; n=6$ (eye samples in each group). $* P<0.05$ vs. control; ${ }^{\#} P<0.05$ vs. blue LED.

Abbreviations: $\beta E_{2}, 17 \beta$-estradiol; LED, light-emitting diode.

\section{$\beta \mathrm{E}_{2}$ mitigates $\mathrm{H}_{2} \mathrm{O}_{2}$-induced cell death in APRE- 19 cells}

ARPE-19 cells were treated with 0, 20, 30, 40, 50, 60, 70, and $80 \mu \mathrm{mol} / \mathrm{L}(\mu \mathrm{M}) \mathrm{H}_{2} \mathrm{O}_{2}$ for 24 hours. The CCK-8 assay was performed after removing the $\mathrm{H}_{2} \mathrm{O}_{2}$. As shown in Figure 5, $\mathrm{H}_{2} \mathrm{O}_{2}$ reduced cell viability in a dose-dependent manner. The $\mathrm{IC}_{50}$ of $\mathrm{H}_{2} \mathrm{O}_{2}$ in ARPE-19 cells was $43.18 \pm 0.85 \mu \mathrm{M}$ (Figure 5A). We therefore chose $40 \mu \mathrm{M}$ as a reference concentration for the following experiments.

To assess the protective role of $\beta \mathrm{E}_{2}$, the cells were treated with $0,1,10,40,60$, and $80 \mu \mathrm{M} \beta \mathrm{E}_{2}$ for 2 hours before exposure to $40 \mu \mathrm{mol} / \mathrm{L}$ of $\mathrm{H}_{2} \mathrm{O}_{2}$ for 24 hours. As demonstrated in Figure $5 \mathrm{~B}$, treatment with $40 \mu \mathrm{M} \mathrm{H}_{2} \mathrm{O}_{2}$ significantly decreased cell viability. Pretreatment with $10 \mu \mathrm{M} \beta \mathrm{E}_{2}$ significantly increased cell viability.

\section{$\beta \mathrm{E}_{2}$ decreases $\mathrm{H}_{2} \mathrm{O}_{2}$-induced ROS production in ARPE-19}

To determine the effect of $\beta \mathrm{E}_{2}$ on the intracellular production of ROS, DCF fluorescence was recorded by flow cytometry.
The results revealed that mean fluorescence (ie, intracellular ROS production) increased significantly in the cells that had been exposed to $40 \mu \mathrm{M} \mathrm{H}_{2} \mathrm{O}_{2}$. In addition, pretreatment of the cells with $\beta \mathrm{E}_{2}$ inhibited the intracellular production of ROS (Figure 6).

\section{$\beta \mathrm{E}_{2}$ protects against $\mathrm{H}_{2} \mathrm{O}_{2}$-induced cell apoptosis in APRE- 19 cells}

Apoptosis was detected using the annexin V/PI assay. As shown in Figure $7 \mathrm{~A}$ and $\mathrm{B}, \mathrm{H}_{2} \mathrm{O}_{2}$ significantly increased early apoptosis after treatment. After pretreatment with $\beta \mathrm{E}_{2}$, apoptosis was significantly decreased. To further explore the molecular mechanism underlying the $\beta \mathrm{E}_{2}$ antiapoptosis effect in $\mathrm{H}_{2} \mathrm{O}_{2}$-treated ARPE-19 cells, we measured Akt, phosphoAkt, Bax, Bcl-2, and cleaved caspase-3 protein levels. $\mathrm{H}_{2} \mathrm{O}_{2}$ significantly downregulated the expression of phospho-Akt and Bcl-2 and upregulated the expression of Bax in ARPE-19 cells, whereas pretreatment with $\beta \mathrm{E}_{2}$ reversed these molecular events (Figure 7C and D). 
A

A Control
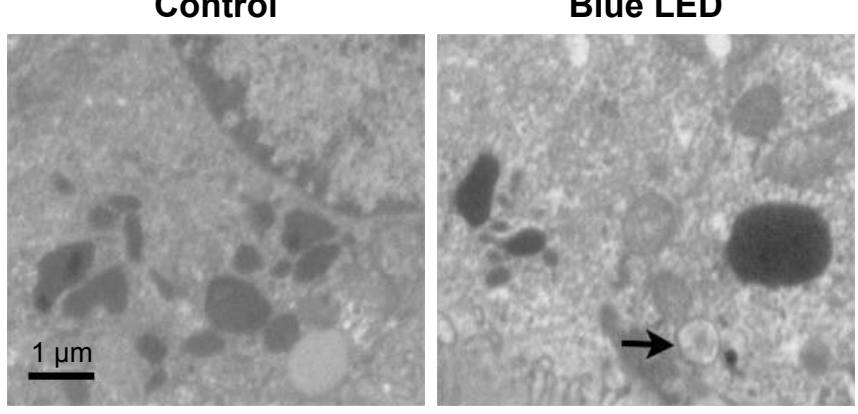

$\beta E_{2}+$ blue LED

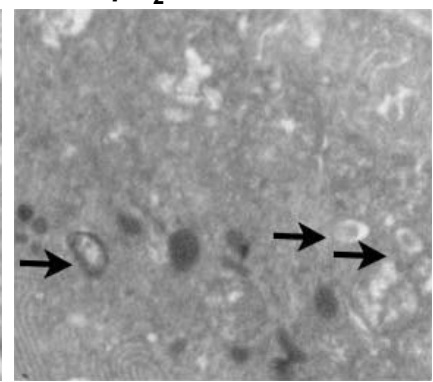

B

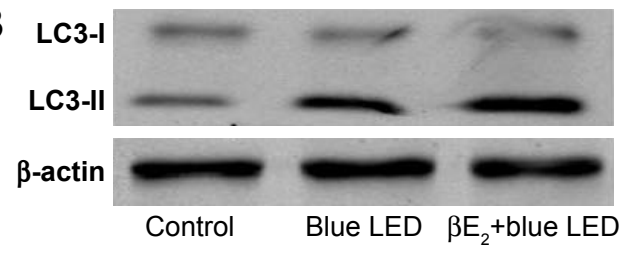

C

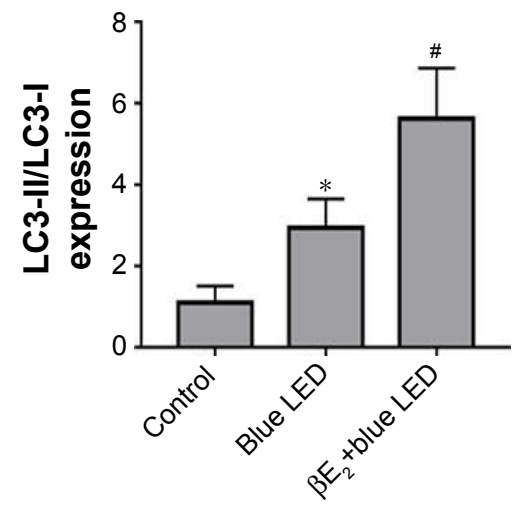

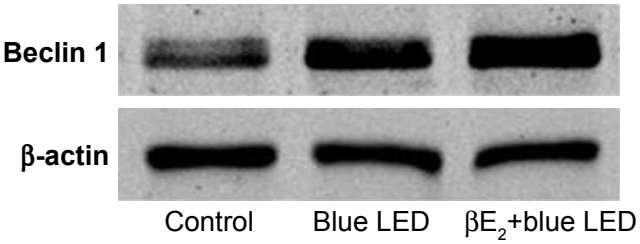

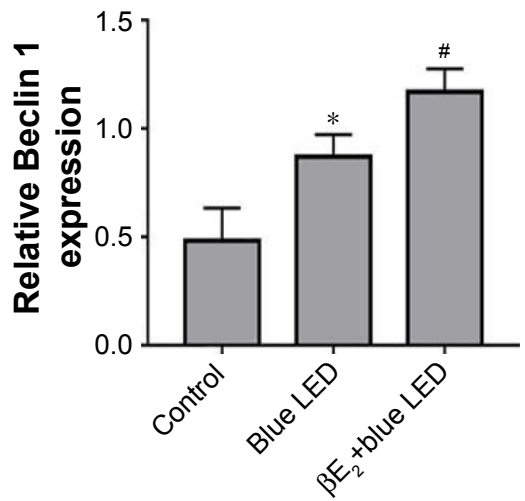

D

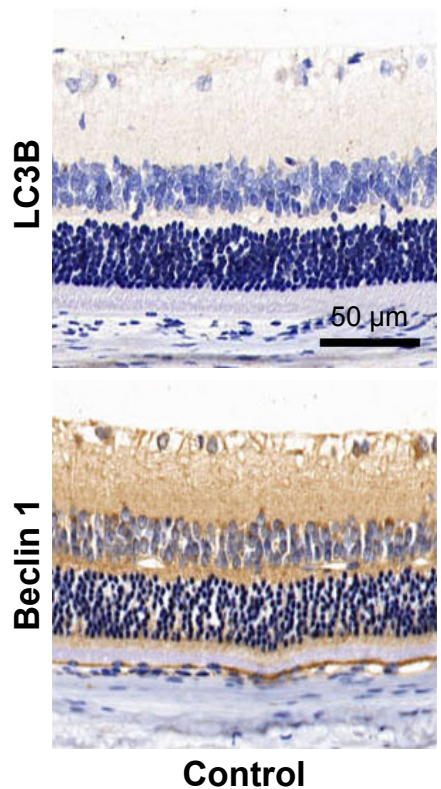

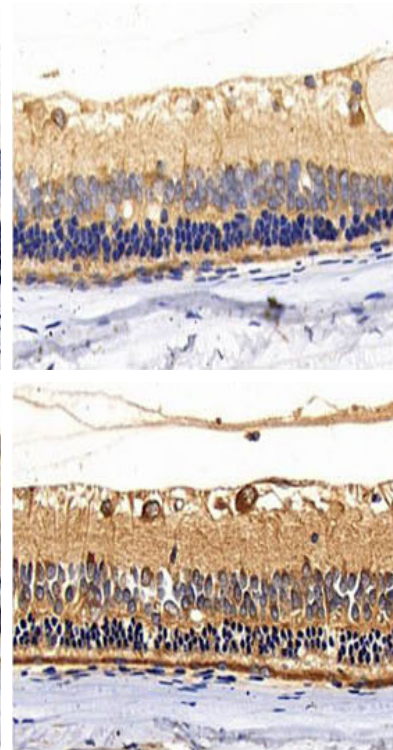

Blue LED
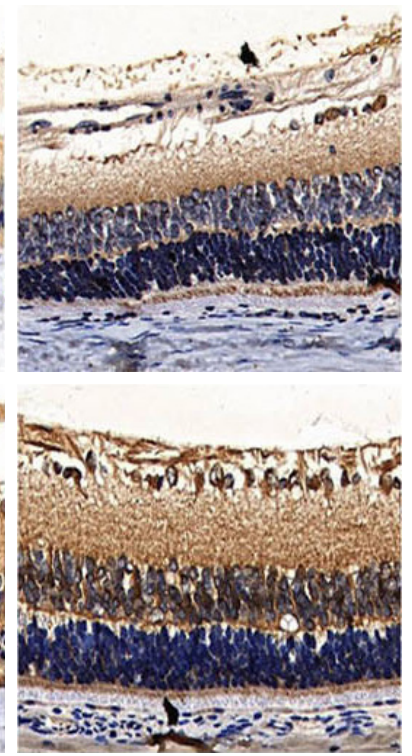

$\beta E_{2}$ +blue LED

Figure $4 \beta \mathrm{E}_{2}$ administration enhances autophagy after blue LED exposure.

Notes: (A) Autophagosomes (black arrows) were examined by electron microscopy. (B) LC3-II, LC3-I and Beclin I protein levels were examined by western blotting. (C) Statistical analysis of western blots. (D) LC3B and Beclin I expression levels were examined by immunohistochemistry. The data represent the mean \pm SEM; $n=6$ (eye samples in each group). $* P<0.05$ vs. control; ${ }^{\# P}<0.05$ vs. blue LED.

Abbreviations: $\beta \mathrm{E}_{2}, 17 \beta$-estradiol; LED, light-emitting diode. 

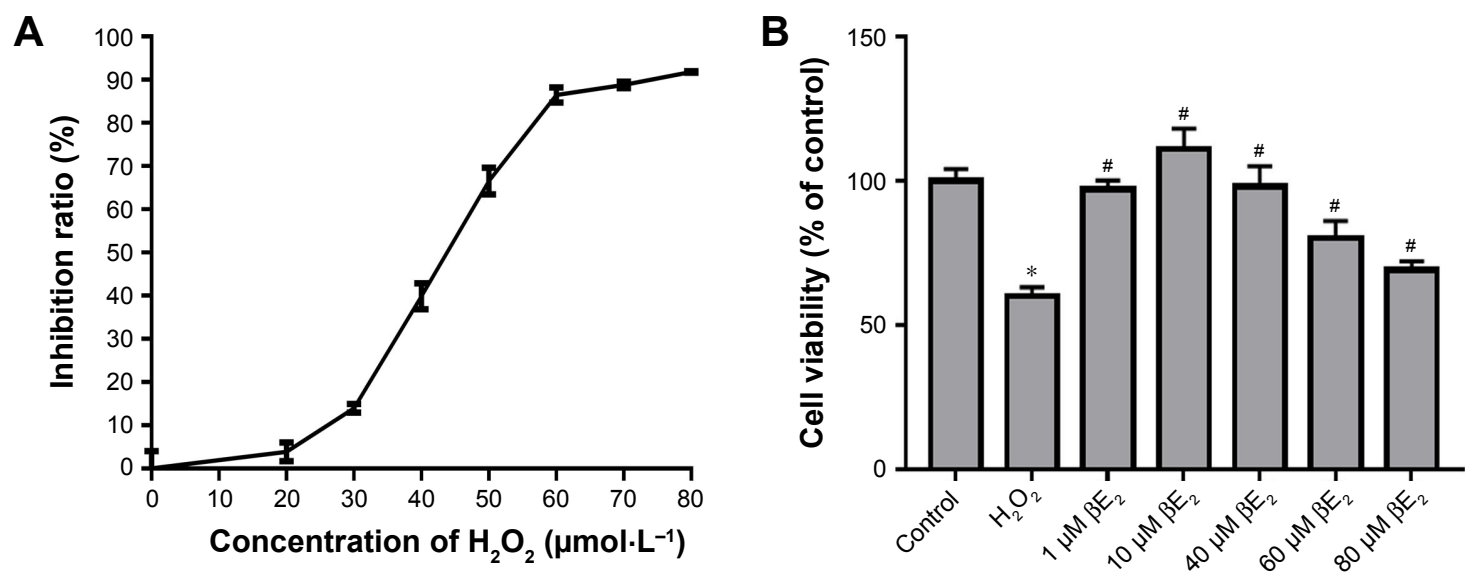

Figure 5 Cell viability assay.

Notes: (A) Different concentrations of $\mathrm{H}_{2} \mathrm{O}_{2}$ affected cell viability, as detected using a CCK-8 assay. (B) The cells were treated with different concentrations of $\beta E_{2}$ for $2 \mathrm{~h}$ before exposure to $40 \mu \mathrm{M}$ of $\mathrm{H}_{2} \mathrm{O}_{2}$ for $24 \mathrm{~h}$, and cell viability was measured using a CCK-8 assay. The data are shown as the mean $\pm S E M$; $n=3$. $* P<0.05$ vs. control; ${ }^{\#} P<0.05$ vs. $\mathrm{H}_{2} \mathrm{O}_{2}$ treatment.

Abbreviations: $\beta \mathrm{E}_{2}, 17 \beta$-estradiol; $\mathrm{H}_{2} \mathrm{O}_{2}$, hydrogen peroxide.

\section{$\beta \mathrm{E}_{2}$ enhanced $\mathrm{H}_{2} \mathrm{O}_{2}$-induced autophagy in} APRE-19 cells

As shown in Figure $8 \mathrm{~A}, \mathrm{H}_{2} \mathrm{O}_{2}$ resulted in a greater than $100 \%$ increase in the number of autophagosomes, and $\beta \mathrm{E}_{2}$ pretreatment enhanced the events in $\mathrm{H}_{2} \mathrm{O}_{2}$-treated ARPE-19 cells. Moreover, $\mathrm{H}_{2} \mathrm{O}_{2}$ upregulated the mRNA expression of Beclin 1 and LC3B, an autophagy-related gene, and $\beta \mathrm{E}_{2}$ pretreatment significantly further enhanced the mRNA expression of Beclin 1 and LC3-II/LC3-I (Figure 8B).
Additionally, we also found that $\mathrm{H}_{2} \mathrm{O}_{2}$ significantly increased Beclin 1 and LC3-II/LC3-I protein levels and that pretreatment with $\beta \mathrm{E}_{2}$ significantly further enhanced the effect of $\mathrm{H}_{2} \mathrm{O}_{2}$ on Beclin 1 and LC3-II/LC3-I protein expression (Figure 8C and D).

\section{Discussion}

In this present study, we demonstrated that blue LED emission could induce an RD model in rats and that pretreatment
A

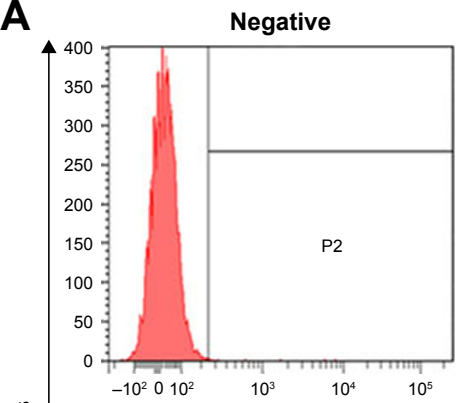

ํㅗㅀ

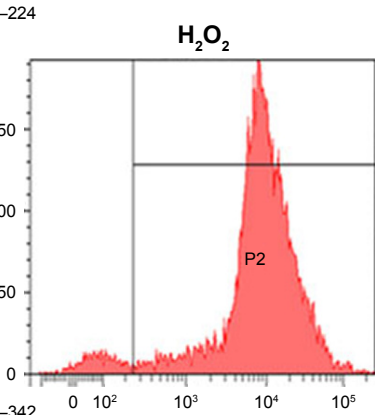

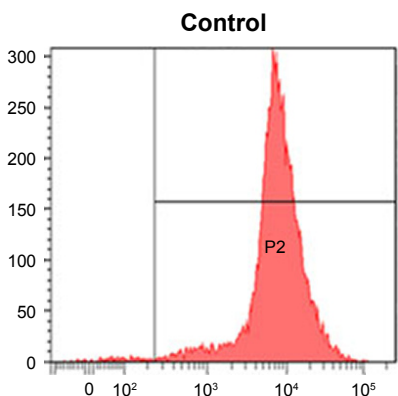

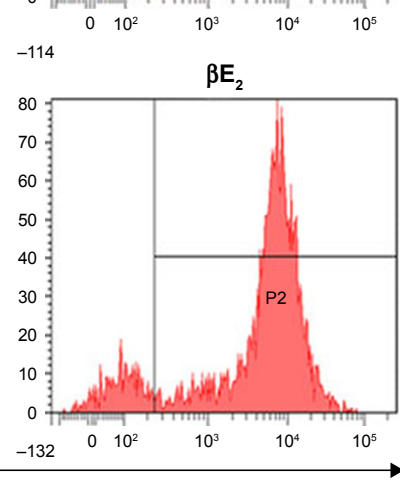

B

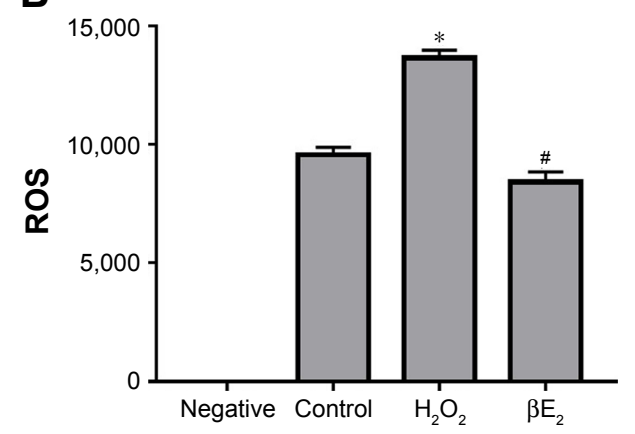

FITC-A

Figure $6 \beta \mathrm{E}_{2}$ prevents ROS production in $\mathrm{H}_{2} \mathrm{O}_{2}$-treated ARPE-19 cells. The cells were treated with $10 \mu \mathrm{M} \beta \mathrm{E}_{2}$ for $2 \mathrm{~h}$ before exposure to $40 \mu \mathrm{M} \mathrm{H}_{2} \mathrm{O}{ }_{2}$ for $24 \mathrm{~h}$. Notes: (A) Intracellular ROS levels were measured using DCF fluorescence. (B) Statistical analysis of intracellular ROS levels. The data are shown as the mean \pm SEM; $n=3$. $* \mathrm{P}<0.05$ vs. control; ${ }^{\# P}<0.05$ vs. $\mathrm{H}_{2} \mathrm{O}_{2}$ treatment.

Abbreviations: $\beta E_{2}, 17 \beta$-estradiol; FITC-A, . 
with $\beta \mathrm{E}_{2}$ had a protective effect on blue LED emissioninduced RD by decreasing apoptosis and enhancing autophagy in vivo. We also found that $\beta \mathrm{E}_{2}$ pretreatment had the same protective effect against $\mathrm{H}_{2} \mathrm{O}_{2}$ treatment in ARPE-19 cells in vitro. These results indicated that $\beta \mathrm{E}_{2}$ represents a promising potential treatment in the clinic for retinal degenerative disorders, such as AMD.

Light-induced RD is a popular model of oxidative stress, which has been implicated in the pathogenesis of AMD. ${ }^{35,36}$ In vitro and in vivo RD models have recently been introduced using LED illumination; due to their low energy consumption, LEDs are considered an important light source for replacing conventional lights. LED-induced $\mathrm{RD}$ is wavelength dependent but is not energy dependent. ${ }^{5}$ Researchers have begun using a blue LED-induced RD model in the study of RD pathophysiology and in the evaluation of the effects of new therapeutic agents. ${ }^{7,37,38}$ Exposure to blue LED $(460 \mathrm{~nm})$ is well known to cause retinal histopathological and functional changes in animals. ${ }^{39}$ Therefore, we first evaluated the effect of blue LED (460 nm) exposure on retinal function and morphology using ERG and HE, respectively. We found that rats exposed to blue LED emission exhibited significantly decreased ERG a- and b-wave amplitudes and massive photoreceptor loss, retinal cell pyknosis, and a reduction in the thickness of the ONL. These results are consistent with those obtained in an earlier study. ${ }^{39}$

A neuroprotective effect has previously been shown for estrogen, a therapeutic agent used to treat Alzheimer's disease and Parkinson's disease, in various neuronal cells and animal models of central neurological disorders. ${ }^{10,11} \beta \mathrm{E}_{2}$ also protects against light-induced retinal damage. ${ }^{40}$ However, no study has evaluated the effect of $\beta \mathrm{E}_{2}$ on blue-LED-induced retinal damage In this study, we first evaluated the effect of $\beta \mathrm{E}_{2}$ on blue LED-induced retinal dysfunction using ERG. In in vivo studies, rats were intravitreally injected with $4 \mu \mathrm{L}$ of $10 \mu \mathrm{M} \beta \mathrm{E}_{2}$; this was found to be the most effective treatment dose. After treatment, the rats were allowed to recover for 4 hours before exposure to light damage. ${ }^{14,21,32}$
A
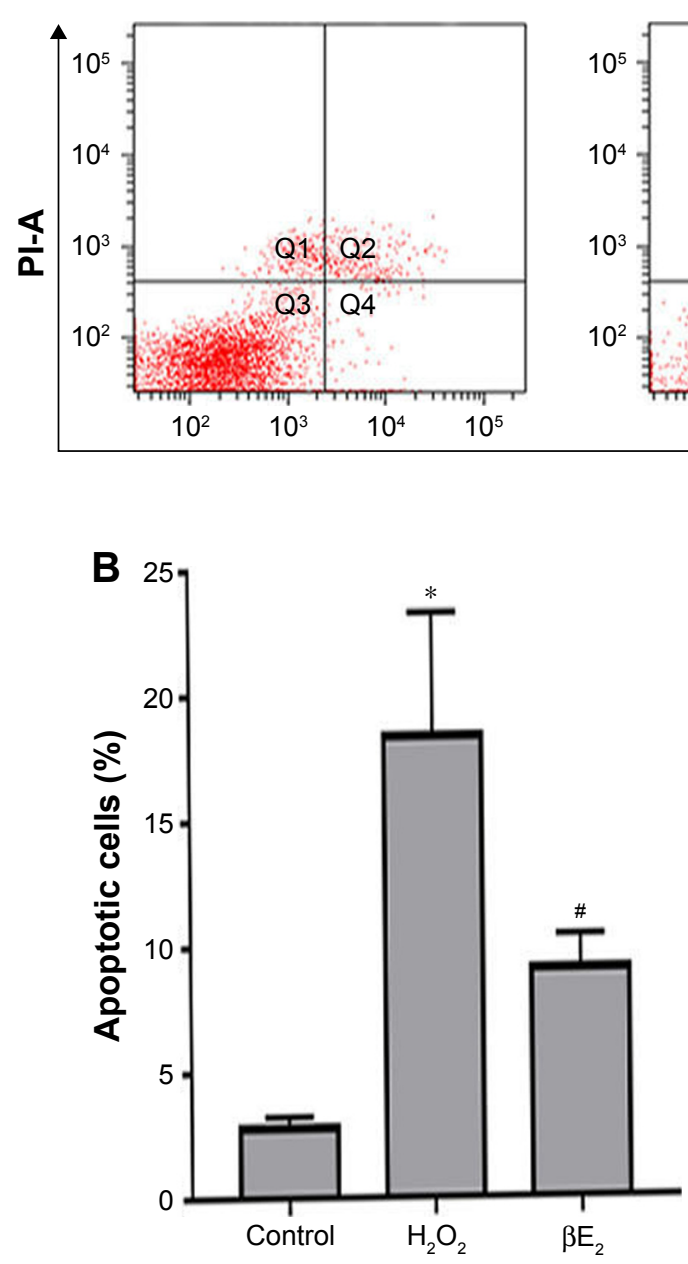
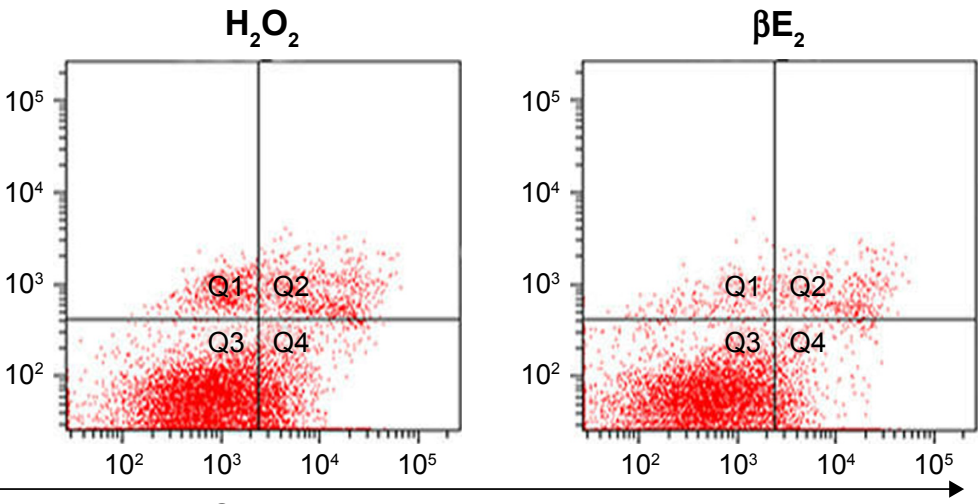

FITC-A

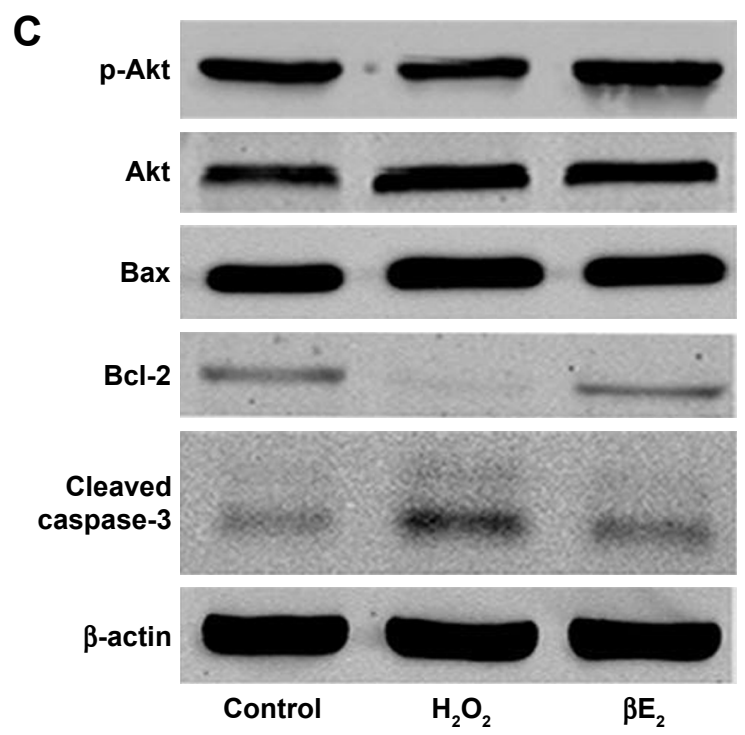

Figure 7 (Continued) 

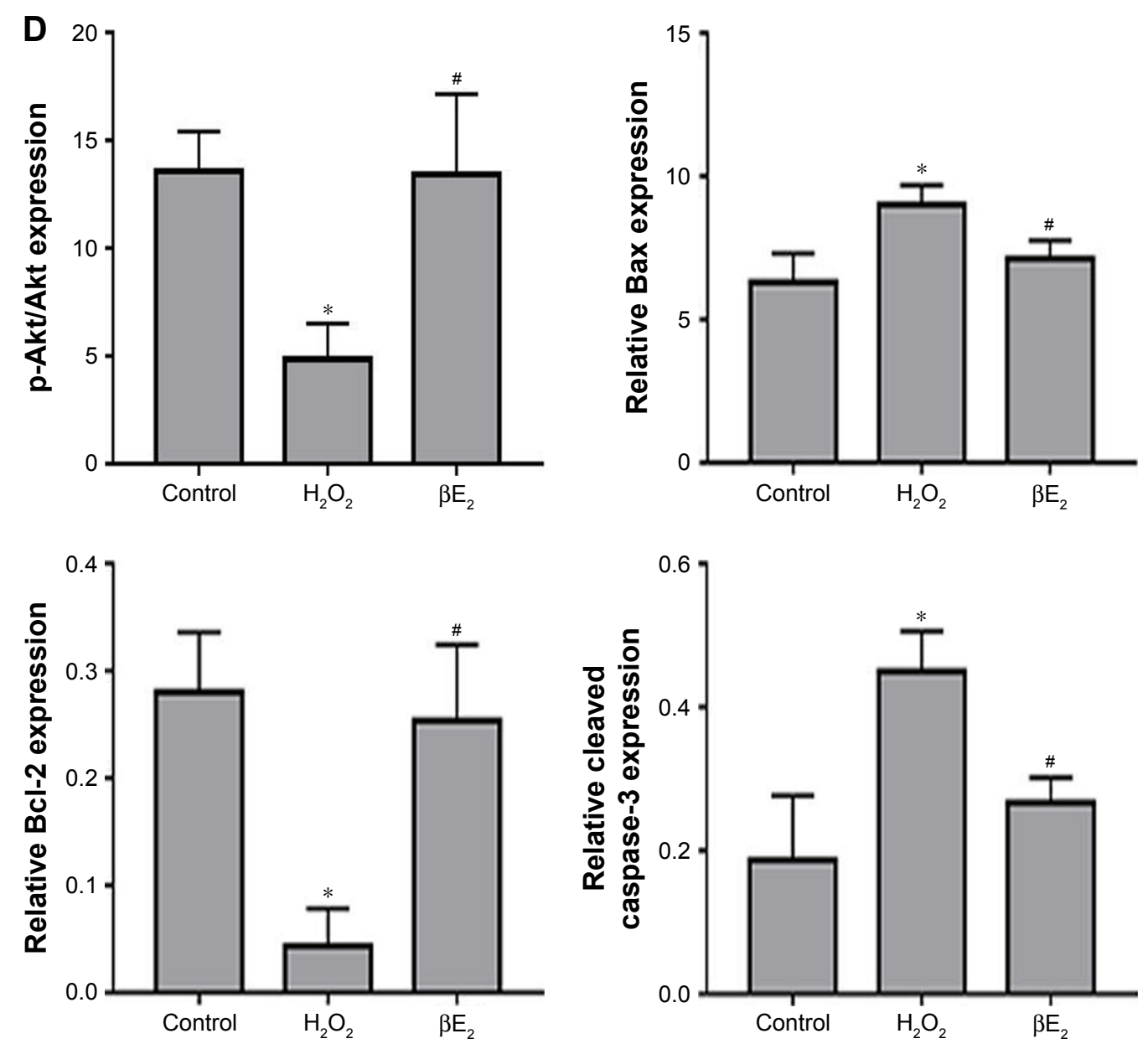

Figure $7 \mathrm{E}_{2}$ treatment decreases $\mathrm{H}_{2} \mathrm{O}_{2}$-induced apoptosis in APRE-19 cells. The cells were treated with $10 \mu \mathrm{M} \beta \mathrm{E}_{2}$ for 2 hours before exposure to $40 \mu \mathrm{M} \mathrm{H}_{2} \mathrm{O}_{2}$ for 24 h. Notes: (A) Apoptosis was detected by Annexin V/PI staining. (B) The statistical analysis of apoptotic cells. (C) Bax, Bcl-2, Cleaved caspase 3, Akt and p-Akt protein levels were examined by western blotting. (D) Statistical analysis of western blot data. The data are shown as the mean $\pm S E M ; n=3$. $* P<0.05$ vs. control; ${ }^{*} P<0.05$ vs. $\mathrm{H}_{2} \mathrm{O}_{2}$ treatment. Abbreviations: $\beta \mathrm{E}_{2}, 17 \beta$-estradiol; FITC, fluorescein isothiocyanate; $\mathrm{PI}$, propidium iodide.

Hence, in this study, $4 \mu \mathrm{L}$ of $10 \mu \mathrm{M} \beta \mathrm{E}_{2}$ was administered to the rats 4 hours before blue LED exposure. Vehicle-treated rats exhibited a significant decrease in ERG a- and b-wave amplitudes after blue LED emission exposure, and $\beta \mathrm{E}_{2}$ significantly prevented blue LED-induced retinal dysfunction. We then performed morphologic studies. We found a severe disruption of retinal morphology in vehicle-treated mice after exposure to blue LED emission. Treatment with $\beta \mathrm{E}_{2}$ prevented photoreceptor loss and reductions in the thickness of the ONL.

Recent in vitro and in vivo reports have demonstrated that full-spectrum LEDs with a blue $(460 \mathrm{~nm})$ component significantly decrease metabolic activity and MMP while increasing intracellular ROS levels and the expression of oxidative stress marker proteins, such as heme oxygenase-1, manganese superoxide dismutase, $8-\mathrm{OHdG}$, and nitrotyrosine, in human RPE cells and rodent retinas. ${ }^{5,6,37,38}$ Although the exact cause of AMD is unknown, oxidative stress likely plays an important role in its pathogenesis. ${ }^{41}$ Several in vitro and in vivo studies have shown that $\beta \mathrm{E}_{2}$ protects $\mathrm{RPE}$ from oxidative stress. ${ }^{41-43}$ To investigate the antioxidant ability of $\beta \mathrm{E}_{2}$ in retinal cells, we first evaluated the effect of 1-10 $\mu \mathrm{M} \beta \mathrm{E}_{2}$ on $\mathrm{H}_{2} \mathrm{O}_{2}$-induced human ARPE-19 cell death and found that pretreatment with $10 \mu \mathrm{M} \beta \mathrm{E}_{2}$ significantly decreased ARPE-19 cell death. We then assessed changes in ROS generation following $\beta \mathrm{E}_{2}$ treatment and found that $\beta \mathrm{E}_{2}$ significantly decreased ROS production. This finding is consistent with previous reports ${ }^{14,15}$ and suggests that $\beta \mathrm{E}_{2}$ also exerts antioxidant properties in retinal cells.

Apoptosis is a well-known mechanism resulting in cell death in AMD patients and experimental RD models. ${ }^{44,45}$ It has also been reported that exposing the retina to blue LED emission leads to massive photoreceptor cell death in the ONL. ${ }^{39}$ Pretreatment with exogenous $\mathrm{E}_{2}$ has been shown to inhibit apoptosis and to protect the cerebrum from neuronal oxidative damage in primary neuronal cultures and in vivo models. ${ }^{46,47} \beta \mathrm{E}_{2}$ also has important significance for the prevention of cell apoptosis caused by light-induced 

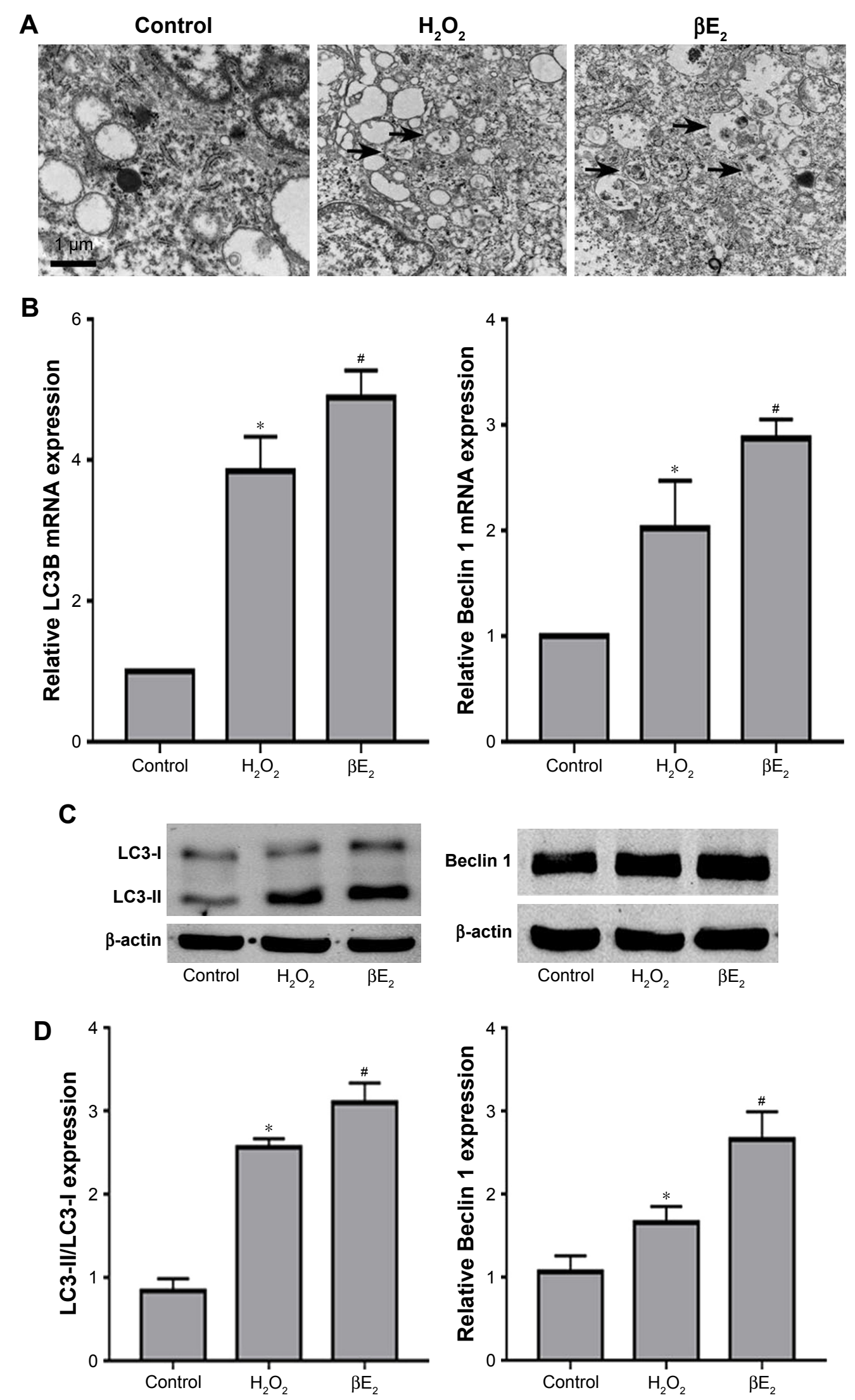

Figure $8 \mathrm{BE}_{2}$ enhances $\mathrm{H}_{2} \mathrm{O}_{2}$-induced cell autophagy in APRE-19 cells. The cells were treated with $10 \mu \mathrm{M} \beta \mathrm{E}_{2}$ for $2 \mathrm{~h}$ before exposure to $40 \mu \mathrm{M} \mathrm{H}_{2} \mathrm{O}_{2}$ for $24 \mathrm{~h}$.

Notes: (A) Autophagosomes (black arrows) were examined by electron microscopy. (B) LC3B and Beclin ImRNA expression levels were examined by qRT-PCR. (C) LC3-II, LC3-I and Beclin I protein levels were examined by western blotting. (D) The statistical analysis of western blot data. The data are shown as the mean \pm SEM; $n=3$. $* P<0.05$ vs. control; ${ }^{*} \mathrm{P}<0.05$ vs. $\mathrm{H}_{2} \mathrm{O}_{2}$ treatment.

Abbreviation: $\beta \mathrm{E}_{2}$, I7 $\beta$-estradiol. 
retinal damage..$^{21}$ In this study, the number of TUNELpositive cells in the ONL was significantly increased in vehicle-treated mice after blue LED emission exposure. Treatment with $\beta \mathrm{E}_{2}$ prevented a reduction in the number of TUNEL-positive cells. These findings suggest that $\beta \mathrm{E}_{2}$ can suppress the photoreceptor cell death caused by exposure to blue LED emission and ameliorate the impairment of visual function. We also assessed apoptosis in $\mathrm{H}_{2} \mathrm{O}_{2}$-induced ARPE-19 cells after $\beta \mathrm{E}_{2}$ pretreatment and found that $\beta \mathrm{E}_{2}$ induces apoptosis.

In the past several years, many signaling molecules in the membrane-initiated steroid signaling pathway have been reported to be neuroprotective and to interact with the PI3K/ Akt pathway, an important survival pathway. ${ }^{48}$ In addition, some studies have demonstrated that neuroprotective function increases the Bcl-2 level to an antiapoptotic state and activates autophagy through the induction of Beclin 1.49,50 Similarly, $\beta \mathrm{E}_{2}$ protects against light-induced retinal damage via the PI3K/Akt signaling pathways. ${ }^{40}$ Microarray analysis of RPE exposed to $\mathrm{H}_{2} \mathrm{O}_{2}$ showed that $\beta \mathrm{E}_{2}$ pretreatment induces the upregulation of apoptosis-related protein and protects the RPE from degeneration. ${ }^{42}$ In the present study, histological and molecular-biological changes demonstrated that the phosphorylation level of AKT was higher after intravitreal $\beta \mathrm{E}_{2}$ administration. Current evidence suggests that the mitochondrial-mediated signal transduction pathway plays a central role in apoptosis. ${ }^{51}$ The intrinsic apoptotic pathway can be activated by excessive ROS levels. This pathway is initiated by the activation of proapoptotic Bcl-2 family proteins (Bid, Bim, Bad, and Bmf) followed by the activation of Bax subfamily Bcl-2 proteins (Bax, Bak, and Bok) that are localized on the outer mitochondrial membrane. Consequently, Bax is released at an increased rate and attacks the mitochondrial membrane, leading to cytochrome $\mathrm{c}$ release and caspase-3 activation, finally triggering apoptosis. ${ }^{52}$ In our experiments, we demonstrated that $\beta \mathrm{E}_{2}$ significantly reduces the expressions of $\mathrm{Bax}$ and caspase-3 and increases the expression of Bcl-2, leading us to conclude that $\beta \mathrm{E}_{2}$ inhibits apoptosis through the upregulation of Bcl-2 and the downregulation of Bax and caspase-3 during blue LED-induced $\mathrm{RD}$ and in $\mathrm{H}_{2} \mathrm{O}_{2}$-treated ARPE-19 cells. This effect may occur through activation of the PI3K signaling pathway.

Reports on autophagy in the retina include RD following acute light exposure or damage to retinal ganglion cells following optic nerve transection and the regulation of autophagy in RPE cells..$^{24,25,53-55}$ Autophagy is associated with RPE damage and AMD pathology. ${ }^{25,56}$ Autophagy-related proteins have recently been found to be strongly expressed in the retina. ${ }^{25,57}$ Beclin 1 sits at the center of pathways that regulate and induce autophagy. ${ }^{25,58} \mathrm{LC} 3$ has been regarded as a primary biochemical marker for autophagy activation. The conversion of the soluble form of LC3 (LC3-I) to the autophagic vesicle-associated form (LC3-II) is indicative of autophagic flux and has been regarded as a reliable autophagy marker. ${ }^{59}$ Studies have shown that autophagy is increased in the earliest AMD stages, whereas in the latter stages of the disease, autophagy is lost. Acute exposure to $\mathrm{H}_{2} \mathrm{O}_{2}$ caused an increase in autophagy-related proteins, while chronic oxidative stress reduced the expression of several key autophagy-related proteins. ${ }^{60}$ Recently, several studies have demonstrated that Beclin 1 can downregulate estrogenic pathway, suggesting the importance of the interaction between $\mathrm{E}_{2}$ and autophagy. ${ }^{61}$ In the present study, we found that blue LED exposure increased autophagy markers and that $\beta \mathrm{E}_{2}$ administration further enhanced this increase in autophagy markers. These data were corroborated by our analysis of electron micrographs, which demonstrated a further increase in autophagosomes in the $\beta \mathrm{E}_{2}$-pretreated rats when compared to the rats exposed to blue LED emission. The increased level of autophagy might be activated by the Beclin 1 signaling pathway. Our in vitro Western blot and qRT-PCR data also demonstrated that the level of autophagy was increased in acute $\mathrm{H}_{2} \mathrm{O}_{2}$-treated ARPE-19 cells, while $\beta \mathrm{E}_{2}$ pretreatment was able to enhance the autophagy level. Taken together, these results show that its potent ability to enhance autophagy may be a key factor in the retinal protective effect of $\beta \mathrm{E}_{2}$.

\section{Conclusion}

Pretreatment with $\beta \mathrm{E}_{2}$ induced a remarkable protection against blue LED-induced $\mathrm{RD}$ and $\mathrm{H}_{2} \mathrm{O}_{2}$-induced oxidative stress, and this protection is likely to occur through a reduction in apoptosis and increased autophagy. These findings may aid in the development of a future clinical strategy for the treatment of retinal degenerative disorders such as AMD.

\section{Acknowledgments}

This work was supported by the National Natural Science Foundation of China in 2014 (project number: 81470648) and the Fundamental Research Funds for the Central Universities. The authors also thank AJE for English editing. An abstract of this paper was presented at the 10th Chinese Congress of Research in Vision and Ophthalmology (CCRVO) as a poster presentation.

\section{Disclosure}

The authors report no conflicts of interest in this work. 


\section{References}

1. Kaarniranta K, Salminen A. Age-related macular degeneration: activation of innate immunity system via pattern recognition receptors. J Mol Med (Berl). 2009;87(2):117-123.

2. Resnikoff S, Pascolini D, Etya'ale D, et al. Global data on visual impairment in the year 2002. Bull World Health Organ. 2004;82(11): 844-851.

3. Taylor HR, Muñoz B, West S, Bressler NM, Bressler SB, Rosenthal FS. Visible light and risk of age-related macular degeneration. Trans Am Ophthalmol Soc. 1990;88:163-173.

4. Noell WK, Walker VS, Kang BS, Berman S. Retinal damage by light in rats. Invest Ophthalmol. 1966;5(5):450-473.

5. Kuse Y, Ogawa K, Tsuruma K, Shimazawa M, Hara H. Damage of photoreceptor-derived cells in culture induced by light emitting diodederived blue light. Sci Rep. 2014;4:5223.

6. Behar-Cohen F, Martinsons C, Viénot F, et al. Light-emitting diodes (LED) for domestic lighting: any risks for the eye? Prog Retin Eye Res. 2011;30(4):239-257.

7. Berson DM, Dunn FA, Takao M. Phototransduction by retinal ganglion cells that set the circadian clock. Science. 2002;295(5557): 1070-1073.

8. Kagan DB, Liu H, Hutnik CM. Efficacy of various antioxidants in the protection of the retinal pigment epithelium from oxidative stress. Clin Ophthalmol. 2012;6:1471-1476.

9. Malone L, Schuler C, Leggett RE, Levin RM. Effect of estrogen and ovariectomy on response of the female rabbit urinary bladder to two forms of in vitro oxidative stress. Int Urogynecol J. 2014;25(6):791-798.

10. Amtul Z, Wang L, Westaway D, Rozmahel RF. Neuroprotective mechanism conferred by 17 beta-estradiol on the biochemical basis of Alzheimer's disease. Neuroscience. 2010;169(2):781-786.

11. Jimenez del Rio M, Velez-Pardo C. 17 beta-estradiol protects lymphocytes against dopamine and iron-induced apoptosis by a genomic-independent mechanism: implication in Parkinson's disease. Gen Pharmacol. 2000;35(1):1-9.

12. Quintanilla RA, Muñoz FJ, Metcalfe MJ, et al. Trolox and 17betaestradiol protect against amyloid beta-peptide neurotoxicity by a mechanism that involves modulation of the Wnt signaling pathway. J Biol Chem. 2005;280(12):11615-11625.

13. Ba F, Pang PK, Davidge ST, Benishin CG. The neuroprotective effects of estrogen in SK-N-SH neuroblastoma cell cultures. Neurochem Int. 2004;44(6):401-411.

14. Wang S, Wang B, Feng Y, et al. 17 $\beta$-estradiol ameliorates light-induced retinal damage in Sprague-Dawley rats by reducing oxidative stress. J Mol Neurosci. 2015;55(1):141-151.

15. Giddabasappa A, Bauler M, Yepuru M, Chaum E, Dalton JT, Eswaraka J. $17-\beta$ estradiol protects ARPE-19 cells from oxidative stress through estrogen receptor- $\beta$. Invest Ophthalmol Vis Sci. 2010;51(10):5278-5287.

16. Dunaief JL, Dentchev T, Ying GS, Milam AH. The role of apoptosis in age-related macular degeneration. Arch Ophthalmol. 2002;120(11): 1435-1442.

17. Marc RE, Jones BW, Watt CB, Vazquez-Chona F, Vaughan DK, Organisciak DT. Extreme retinal remodeling triggered by light damage: implications for age related macular degeneration. Mol Vis. 2008; 14:782-806.

18. Hanus J, Anderson C, Wang S. RPE necroptosis in response to oxidative stress and in AMD. Ageing Res Rev. 2015;24(Pt B):286-298.

19. Simpkins JW, Wang J, Wang X, Perez E, Prokai L, Dykens JA. Mitochondria play a central role in estrogen-induced neuroprotection. Curr Drug Targets CNS Neurol Disord. 2005;4(1):69-83.

20. Flynn JM, Dimitrijevich SD, Younes M, Skliris G, Murphy LC, Cammarata PR. Role of wild-type estrogen receptor-beta in mitochondrial cytoprotection of cultured normal male and female human lens epithelial cells. Am J Physiol Endocrinol Metab. 2008;295(3):E637-E647.

21. Mo MS, Li HB, Wang BY, Wang SL, Zhu ZL, Yu XR. PI3K/Akt and NF- $\kappa B$ activation following intravitreal administration of $17 \beta$ estradiol: neuroprotection of the rat retina from light-induced apoptosis. Neuroscience. 2013;228:1-12.
22. Kaarniranta K, Sinha D, Blasiak J, et al. Autophagy and heterophagy dysregulation leads to retinal pigment epithelium dysfunction and development of age-related macular degeneration. Autophagy. 2013; 9(7):973-984.

23. Lee J, Giordano S, Zhang J. Autophagy, mitochondria and oxidative stress: cross-talk and redox signalling. Biochem J. 2012;441(2): 523-540.

24. Kim JY, Zhao H, Martinez J, et al. Noncanonical autophagy promotes the visual cycle. Cell. 2013;154(2):365-376.

25. Mitter SK, Rao HV, Qi X, et al. Autophagy in the retina: a potential role in age-related macular degeneration. Adv Exp Med Biol. 2012;723: 83-90.

26. Kunchithapautham K, Rohrer B. Apoptosis and autophagy in photoreceptors exposed to oxidative stress. Autophagy. 2007;3(5):433-441.

27. Kunchithapautham K, Coughlin B, Lemasters JJ, Rohrer B. Differential effects of rapamycin on rods and cones during light-induced stress in albino mice. Invest Ophthalmol Vis Sci. 2011;52(6):2967-2975.

28. Wang F, Xiao J, Shen Y, Yao F, Chen Y. Estrogen protects cardiomyocytes against lipopolysaccharide by inhibiting autophagy. Mol Med Rep. 2014;10(3):1509-1512.

29. Mei J, Zhu XY, Jin LP, Duan ZL, Li DJ, Li MQ. Estrogen promotes the survival of human secretory phase endometrial stromal cells via CXCL12/CXCR4 up-regulation-mediated autophagy inhibition. Hum Reprod. 2015;30(7):1677-1689.

30. Cook KL, Clarke PA, Parmar J, et al. Knockdown of estrogen receptor- $\alpha$ induces autophagy and inhibits antiestrogen-mediated unfolded protein response activation, promoting ROS-induced breast cancer cell death. FASEB J. 2014;28(9):3891-3905.

31. Fan D, Liu SY, van Hasselt CA, et al. Estrogen receptor $\alpha$ induces prosurvival autophagy in papillary thyroid cancer via stimulating reactive oxygen species and extracellular signal regulated kinases. J Clin Endocrinol Metab. 2015;100(4):E561-E571.

32. Chiu K, Chang RC, So KF. Intravitreous injection for establishing ocular diseases model. J Vis Exp. 2007;8(8):313.

33. Green PG, Dahlqvist SR, Isenberg WM, Strausbaugh HJ, Miao FJ, Levine JD. Sex steroid regulation of the inflammatory response: sympathoadrenal dependence in the female rat. J Neurosci. 1999;19(10): 4082-4089.

34. Livak KJ, Schmittgen TD. Analysis of relative gene expression data using real-time quantitative PCR and the 2(-delta delta $\mathrm{C}(\mathrm{T})$ ) method. Methods. 2001;25(4):402-408.

35. Coleman HR, Chan CC, Ferris FL 3rd, Chew EY. Age-related macular degeneration. Lancet. 2008;372(9652):1835-1845.

36. Wenzel A, Grimm C, Samardzija M, Remé CE. Molecular mechanisms of light-induced photoreceptor apoptosis and neuroprotection for retinal degeneration. Prog Retin Eye Res. 2005;24(2):275-306.

37. Ogawa K, Kuse Y, Tsuruma K, Kobayashi S, Shimazawa M, Hara H. Protective effects of bilberry and lingonberry extracts against blue light-emitting diode light-induced retinal photoreceptor cell damage in vitro. BMC Complement Altern Med. 2014;14:120.

38. Zhao L, Wang C, Song D, et al. Systemic administration of the antioxidant/iron chelator $\alpha$-lipoic acid protects against light-induced photoreceptor degeneration in the mouse retina. Invest Ophthalmol Vis Sci. 2014;55(9):5979-5988.

39. Kim GH, Kim HI, Paik SS, Jung SW, Kang S, Kim IB. Functional and morphological evaluation of blue light-emitting diode-induced retinal degeneration in mice. Graefes Arch Clin Exp Ophthalmol. 2016; 254(4):705-716.

40. Zhu C, Wang S, Wang B, et al. 17ß-Estradiol up-regulates Nrf2 via $\mathrm{PI} 3 \mathrm{~K} / \mathrm{AKT}$ and estrogen receptor signaling pathways to suppress lightinduced degeneration in rat retina. Neuroscience. 2015;304:328-339.

41. Elliot S, Catanuto P, Fernandez P, et al. Subtype specific estrogen receptor action protects against changes in MMP-2 activation in mouse retinal pigmented epithelial cells. Exp Eye Res. 2008;86(4):653-660.

42. Yu X, Tang Y, Li F, et al. Protection against hydrogen peroxide-induced cell death in cultured human retinal pigment epithelial cells by 17 betaestradiol: a differential gene expression profile. Mech Ageing Dev. 2005; 126(11):1135-1145. 
43. Cousins SW, Marin-Castaño ME, Espinosa-Heidmann DG, Alexandridou A, Striker L, Elliot S. Female gender, estrogen loss, and Sub-RPE deposit formation in aged mice. Invest Ophthalmol Vis Sci. 2003;44(3):1221-1229.

44. Remé CE, Grimm C, Hafezi F, Marti A, Wenzel A. Apoptotic cell death in retinal degenerations. Prog Retin Eye Res. 1998;17(4):443-464.

45. Ogueta SB, Schwartz SD, Yamashita CK, Farber DB. Estrogen receptor in the human eye: influence of gender and age on gene expression. Invest Ophthalmol Vis Sci. 1999;40(9):1906-1911.

46. Stirone C, Duckles SP, Krause DN, Procaccio V. Estrogen increases mitochondrial efficiency and reduces oxidative stress in cerebral blood vessels. Mol Pharmacol. 2005;68(4):959-965.

47. Zhang QG, Raz L, Wang R, et al. Estrogen attenuates ischemic oxidative damage via an estrogen receptor alpha-mediated inhibition of NADPH oxidase activation. J Neurosci. 2009;29(44):13823-13836.

48. Mannella P, Brinton RD. Estrogen receptor protein interaction with phosphatidylinositol 3-kinase leads to activation of phosphorylated Akt and extracellular signal-regulated kinase $1 / 2$ in the same population of cortical neurons: a unified mechanism of estrogen action. J Neurosci. 2006;26(37):9439-9447.

49. Kinarivala N, Patel R, Boustany R-M, Al-Ahmad A, Trippier PC. Discovery of aromatic carbamates that confer neuroprotective activity by enhancing autophagy and inducing the anti-apoptotic protein B-cell lymphoma 2 (Bcl-2). J Med Chem. 2017;60(23):9739-9756.

50. Chauhan S, Ahmed Z, Bradfute SB, et al. Pharmaceutical screen identifies novel target processes for activation of autophagy with a broad translational potential. Nat Commun. 2015;27(6):8620.

51. Adams JM, Cory S. Life-or-death decisions by the Bcl-2 protein family. Trends Biochem Sci. 2001;26(1):61-66.
52. Green DR. Apoptotic pathways: paper wraps stone blunts scissors. Cell. 2000;102(1):1-4.

53. Chen Y, Sawada O, Kohno H, et al. Autophagy protects the retina from light-induced degeneration. J Biol Chem. 2013;288(11):7506-7518.

54. Suzuki M, Tsujikawa M, Itabe $\mathrm{H}$, et al. Chronic photo-oxidative stress and subsequent MCP-1 activation as causative factors for age-related macular degeneration. J Cell Sci. 2012;125(10):2407-2415.

55. Munemasa Y, Kwong JM, Kim SH, Ahn JH, Caprioli J, Piri N. Thioredoxins 1 and 2 protect retinal ganglion cells from pharmacologically induced oxidative stress, optic nerve transection and ocular hypertension. Adv Exp Med Biol. 2010;664:355-363.

56. Kaarniranta K, Sinha D, Blasiak J, et al. Autophagy and heterophagy dysregulation leads to retinal pigment epithelium dysfunction and development of age-related macular degeneration. Autophagy. 2013; 9(7):973-984.

57. Kim SH, Munemasa Y, Kwong JMK, et al. Activation of autophagy in retinal ganglion cells. J Neurosci Res. 2008;86(13):2943-2951.

58. Cao Y, Klionsky DJ. Physiological functions of Atg6/Beclin 1: a unique autophagy-related protein. Cell Res. 2007;17(10):839-849.

59. Tanida I, Ueno T. Kominami E. LC3 and Autophagy. Methods Mol Biol. 2008;445:77-88.

60. Mitter SK, Song C, Qi X, et al. Dysregulated autophagy in the RPE is associated with increased susceptibility to oxidative stress and AMD. Autophagy. 2014;10(11):1989-2005.

61. Straface E, Vona R, Gambardella L, et al. Cell sex determines anoikis resistance in vascular smooth muscle cells. FEBS Lett. 2009;583(21): $3448-3454$
Drug Design, Development and Therapy

\section{Publish your work in this journal}

Drug Design, Development and Therapy is an international, peerreviewed open-access journal that spans the spectrum of drug design and development through to clinical applications. Clinical outcomes, patient safety, and programs for the development and effective, safe, and sustained use of medicines are the features of the journal, which

\section{Dovepress}

has also been accepted for indexing on PubMed Central. The manuscript management system is completely online and includes a very quick and fair peer-review system, which is all easy to use. Visit http://www.dovepress.com/testimonials.php to read real quotes from published authors. 